\title{
Photochemistry with Plane-Polarized Light: Controlling Photochemical Reactivity via Spatially Selective Excitation
}

\author{
Maksim V. Anokhin and Evgueni E. Nesterov*
}

Department of Chemistry and Biochemistry, Northern Illinois University, DeKalb, IL 60115,

United States

\section{Supporting Information}

\section{Additional Figures}

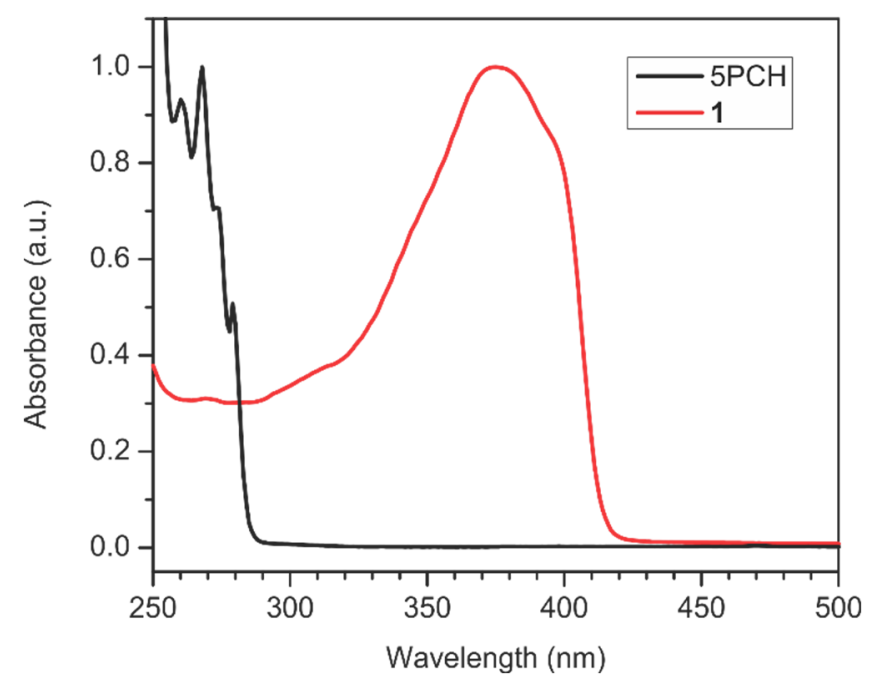

Figure S1. Normalized UV/vis absorption spectra of $5 \mathrm{PCH}$ and compound $\mathbf{1}$ in $\mathrm{CH}_{2} \mathrm{Cl}_{2}$. 

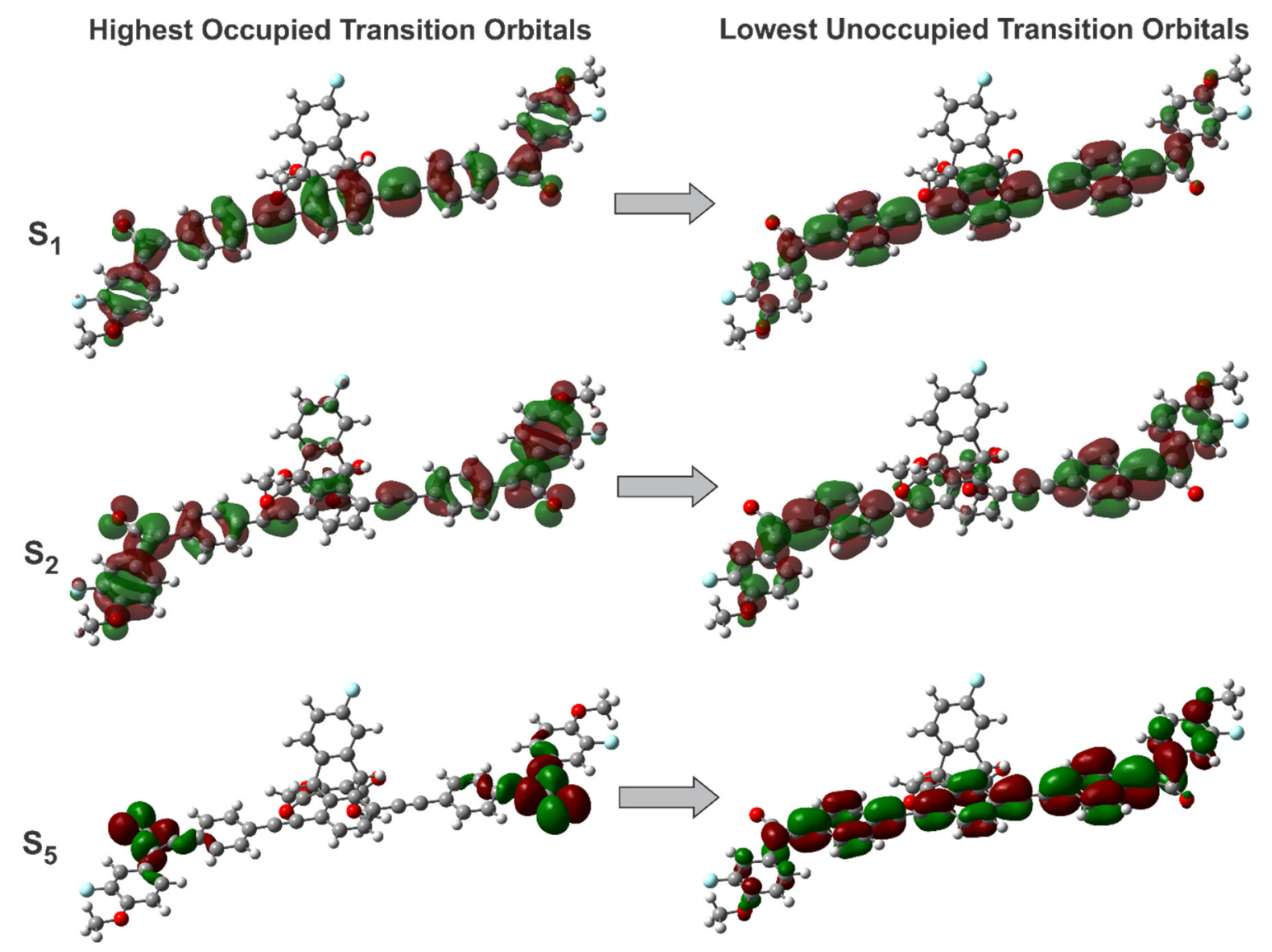

Figure S2. Natural Transition Orbitals corresponding to the excitations to $\mathrm{S}_{1}, \mathrm{~S}_{2}$, and $\mathrm{S}_{5}$ vertical excited states in compound 1 (computed at time-dependent B3LYP/6-31G* level of theory on the ground-state optimized geometry).

\section{Experimental Section}

\section{General Procedures}

All reactions were performed under an atmosphere of dry nitrogen (unless mentioned otherwise). Column chromatography was performed on silica gel (Sorbent Technologies, $60 \AA$, 40-63 $\mu \mathrm{m}$ ) slurry packed into glass columns. Tetrahydrofuran (THF), dichloromethane, and toluene were dried by passing through activated alumina, using a PS-400 Solvent Purification System from Innovative Technology, Inc. The water content of the solvents was periodically controlled by Karl Fischer titration (using a DL32 coulometric titrator from Mettler Toledo). All other solvents (HPLC or anhydrous grade) were used as received. trans-4-(4-Pentylcyclohexyl)benzonitrile $(5 \mathrm{PCH})$ was purchased from Alfa Aesar. All other reagents were obtained from Aldrich, Acros Organics, Alfa Aesar, or TCI America, and used without further purification. Organometallic 
reagents were titrated with salicylaldehyde phenylhydrazone prior to use. ${ }^{1} \mathrm{UV} / \mathrm{vis}$ absorption spectra were recorded on Varian Cary 50 spectrometer. Polarized UV/vis absorption spectra were obtained using Agilent Cary 5000 spectrometer equipped with Harrick Glan-Tompson polarizer (PTH-SMP) installed before an LC cell sample, and depolarizer (DPS-R4V) installed after the sample in order to avoid angular dependence of detector sensitivity to plane-polarized light. The temperature inside the spectrometer sample compartment was kept at $\sim 40{ }^{\circ} \mathrm{C}$ with the help of a small place heater. ${ }^{1} \mathrm{H}$ NMR spectra were recorded at 300 or $500 \mathrm{MHz}$, and are reported in ppm downfield from tetramethylsilane. ${ }^{1} \mathrm{H}$-decoupled ${ }^{19} \mathrm{~F}$ NMR spectra were recorded at 282 or 471 $\mathrm{MHz}$, and are reported in ppm downfield from $\mathrm{CFCl}_{3}$. High resolution mass spectra were obtained at Bruker MaXis Plus LC/MS/MS Q-TOF system using ESI method.

\section{$\underline{\text { Synthetic Details }}$}

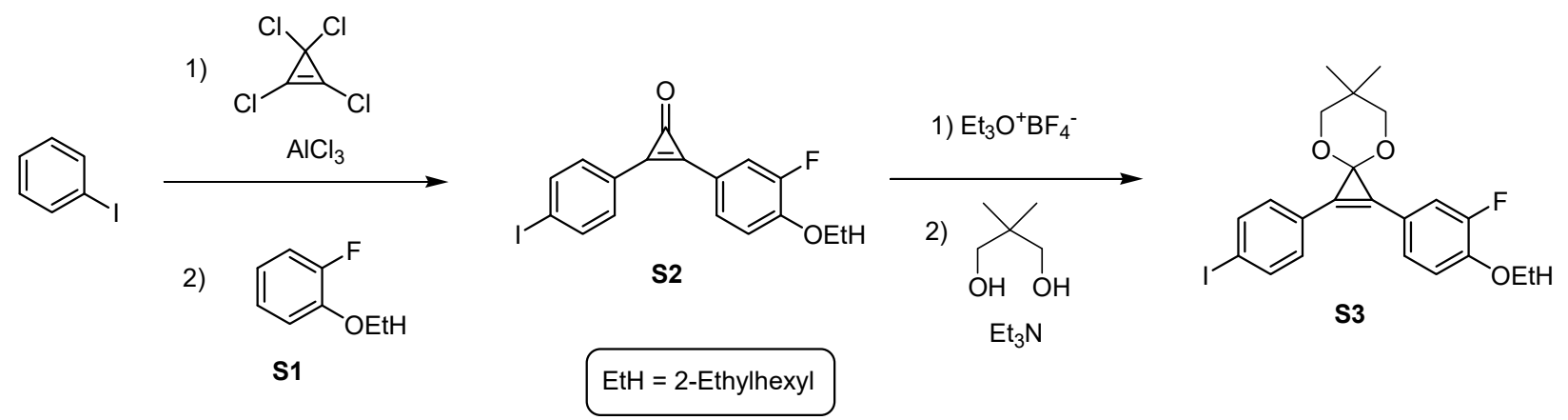

1-((2-Ethylhexyl)oxy)-2-fluorobenzene (S1). A mixture of $3.36 \mathrm{~g}(30.0 \mathrm{mmol})$ of 2fluorophenol, $4.82 \mathrm{~g}(25 \mathrm{mmol})$ of 2-ethylhexyl bromide and $7.0 \mathrm{~g}(50.7 \mathrm{mmol})$ of finely ground anhydrous $\mathrm{K}_{2} \mathrm{CO}_{3}$ in $100 \mathrm{ml}$ of acetonitrile was refluxed under vigorous stirring for $12 \mathrm{~h}$. After allowing to cool down, the mixture was filtered, and the solid on filter was additionally rinsed with $\mathrm{CH}_{2} \mathrm{Cl}_{2}(250 \mathrm{ml})$. The combined filtrate was washed with water, brine, dried over $\mathrm{Na}_{2} \mathrm{SO}_{4}$, and concentrated in vacuo. The crude product was purified by column chromatography on silica gel eluted with hexanes to afford $5.6 \mathrm{~g}(99 \%)$ of $\mathbf{S 1}$ as a colorless oily liquid, $R_{\mathrm{f}} 0.9 .{ }^{1} \mathrm{H}$ NMR (300 $\left.\mathrm{MHz} \mathrm{CDCl}_{3}\right) \delta$ 7.10-6.94 (m, 3H), 6.91-6.84 (m, 1H), 3.91 (d, $\left.J=5.9 \mathrm{~Hz}, 2 \mathrm{H}\right), 1.78$ (septet, $J=$ $5.9 \mathrm{~Hz}, 1 \mathrm{H}), 1.67-1.18(\mathrm{~m}, 8 \mathrm{H}), 1.05-0.75(\mathrm{~m}, 6 \mathrm{H}) .{ }^{19} \mathrm{~F}$ NMR $\left(282 \mathrm{MHz}, \mathrm{CDCl}_{3},{ }^{1} \mathrm{H}\right.$-decoupled) $\delta-134.35$ (s). HRMS (ESI-TOF) $m / z 247.1477[\mathrm{M}+\mathrm{Na}]^{+}$(calcd. for $\mathrm{C}_{14} \mathrm{H}_{21} \mathrm{FO} 247.1474$ ). 


\section{2-(4-((2-ethylhexyl)oxy)-3-fluorophenyl)-3-(4-iodophenyl)cycloprop-2-enone (S2) was}

synthesized following a general procedure by Popik. ${ }^{2}$ A solution of $445 \mathrm{mg}$ (2.5 mmol) of tetrachlorocyclopropene in $2.5 \mathrm{ml}$ of $\mathrm{CH}_{2} \mathrm{Cl}_{2}$ was added dropwise upon stirring to a suspension of $416 \mathrm{mg}$ (3.1 mmol) of $\mathrm{AlCl}_{3}$ in $30 \mathrm{ml}$ of $\mathrm{CH}_{2} \mathrm{Cl}_{2}$ at $-78^{\circ} \mathrm{C}$, and the resulting mixture was stirred at this temperature for $30 \mathrm{~min}$. To the resulting clear mixture, a solution of $510 \mathrm{mg}(2.5 \mathrm{mmol})$ of iodobenzene in $2.5 \mathrm{ml}$ of $\mathrm{CH}_{2} \mathrm{Cl}_{2}$ was added dropwise, the reaction mixture was allowed to reach $0{ }^{\circ} \mathrm{C}$, as the progress of the reaction was monitored by ${ }^{1} \mathrm{H}$ NMR. After stirring for $4 \mathrm{~h}$ at this temperature, only traces of unreacted iodobenzene could be detected. At that point, the reaction mixture was cooled down to $-78{ }^{\circ} \mathrm{C}$, and a solution of $560 \mathrm{mg}(2.5 \mathrm{mmol})$ of $\mathbf{S 1}$ in $5 \mathrm{ml} \mathrm{of} \mathrm{CH}_{2} \mathrm{Cl}_{2}$ was added dropwise over $30 \mathrm{~min}$. Upon completion of the addition, the reaction mixture was allowed to reach $-30{ }^{\circ} \mathrm{C}$, and was stirred for $12 \mathrm{~h}$ at this temperature. After the reaction mixture was allowed to warm to room temperature, it was quenched with saturated $\mathrm{NH}_{4} \mathrm{Cl}$ solution, organic layer was separated, washed with water, brine, dried over $\mathrm{Na}_{2} \mathrm{SO}_{4}$, and concentrated in vacuo. The crude product was purified by column chromatography on silica gel (eluent $\mathrm{CH}_{2} \mathrm{Cl}_{2}$ - ethyl acetate 5:1) to afford $458 \mathrm{mg}(38 \%)$ of $\mathbf{S 2}$ as a beige solid, $R_{\mathrm{f}} 0.25, \mathrm{mp} .112-113{ }^{\circ} \mathrm{C} .{ }^{1} \mathrm{H} \mathrm{NMR}(300 \mathrm{MHz}$, $\left.\mathrm{CDCl}_{3}\right) \delta$ 7.99-7.89 (m, 2H), 7.77-7.56 (m, 4H), $7.11(\mathrm{t}, J=8.3 \mathrm{~Hz}, 1 \mathrm{H}), 4.01(\mathrm{~d}, J=5.9 \mathrm{~Hz}, 2 \mathrm{H})$, 1.81 (septet, $J=5.9 \mathrm{~Hz}, 1 \mathrm{H}), 1.64-1.17(\mathrm{~m}, 8 \mathrm{H}), 1.05-0.75(\mathrm{~m}, 6 \mathrm{H}) .{ }^{19} \mathrm{~F} \mathrm{NMR}\left(282 \mathrm{MHz}, \mathrm{CDCl}_{3}\right.$, ${ }^{1} \mathrm{H}$-decoupled) $\delta-131.97$ (s). HRMS (ESI-TOF) $m / z$ 479.0888 [M+H] $]^{+}$(calcd. for $\mathrm{C}_{23} \mathrm{H}_{24} \mathrm{FIO}_{2}$ 479.0884).

\section{1-(4-((2-ethylhexyl)oxy)-3-fluorophenyl)-2-(4-iodophenyl)-6,6-dimethyl-4,8-}

dioxaspiro[2.5]oct-1-ene (S3) was synthesized in nitrogen atmosphere in a glovebox. A mixture of $95.7 \mathrm{mg}(0.2 \mathrm{mmol})$ of $\mathbf{S 2}$ and $42 \mathrm{mg}(0.22 \mathrm{mmol})$ of freshly recrystallized triethyloxonium tetrafluoroborate in $2.2 \mathrm{ml}$ of $\mathrm{CH}_{2} \mathrm{Cl}_{2}$ was stirred for $3 \mathrm{~h}$ in a $20 \mathrm{ml}$ vial; a precipitate was formed over this period. A solution of $23 \mathrm{mg}(0.22 \mathrm{mmol})$ of neopentyl glycol and $33.3 \mathrm{mg}(0.33 \mathrm{mmol})$ of triethylamine in $2.2 \mathrm{ml}$ of $\mathrm{CH}_{2} \mathrm{Cl}_{2}$ was added dropwise, and the reaction mixture was stirred at room temperature for $12 \mathrm{~h}$, and the progress was periodically monitored by TLC $\left(\mathrm{CH}_{2} \mathrm{Cl}_{2}\right)$. After the reaction was completed, the reaction mixture was concentrated in vacuo. The crude product was purified by column chromatography on silica gel (eluent $0.5 \% \mathrm{Et}_{3} \mathrm{~N}$ in $\mathrm{CH}_{2} \mathrm{Cl}_{2}$ ) to afford 62.7 $\mathrm{mg}(55 \%)$ of $\mathbf{S 3}$ as a waxy beige solid, $R_{\mathrm{f}} 0.8 .{ }^{1} \mathrm{H} \mathrm{NMR}\left(300 \mathrm{MHz}, \mathrm{CD}_{2} \mathrm{Cl}_{2}\right) \delta 8.1-7.33(\mathrm{~m}, 6 \mathrm{H})$, 7.27-7.02 (m, 1H), $4.01(\mathrm{~d}, \mathrm{~J}=6.0 \mathrm{~Hz}, 2 \mathrm{H}), 4.0-3.75(\mathrm{~m}, 1 \mathrm{H}), 3.54-3.33(\mathrm{~m}, 3 \mathrm{H}), 1.83$ (septet, $J=$ $6.0 \mathrm{~Hz}, 1 \mathrm{H}), 1.64-1.20(\mathrm{~m}, 8 \mathrm{H}), 1.15-0.68(\mathrm{~m}, 12 \mathrm{H}) .{ }^{19} \mathrm{~F} \mathrm{NMR}\left(282 \mathrm{MHz}, \mathrm{CD}_{2} \mathrm{Cl}_{2},{ }^{1} \mathrm{H}-\right.$ 
decoupled) $\delta-133.19$ (s). HRMS (ESI-TOF) $m / z 565.1628[\mathrm{M}+\mathrm{H}]^{+}$(calcd. for $\mathrm{C}_{28} \mathrm{H}_{34} \mathrm{FIO}_{3}$ $565.1615)$.
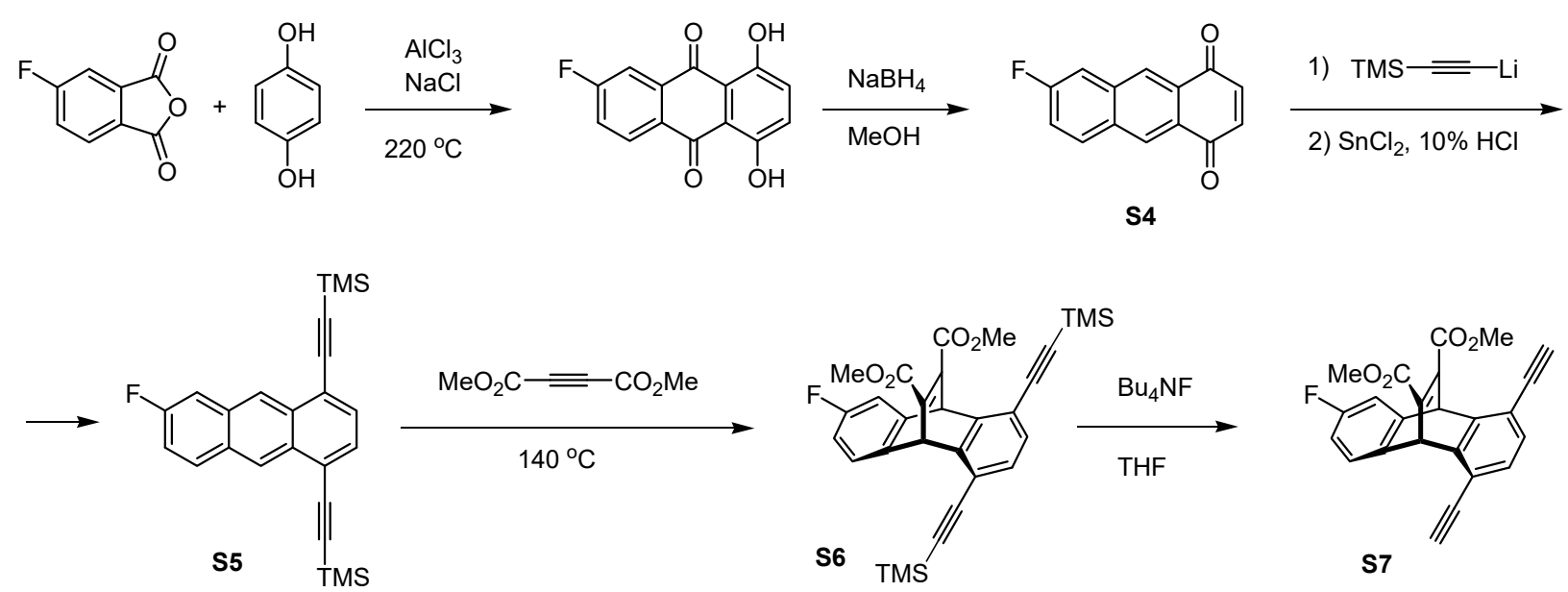

6-Fluoroanthracene-1,4-dione (S4) was prepared following the general procedure by Swager. ${ }^{3} \mathrm{~A}$ mixture of $\mathrm{AlCl}_{3}(5.0 \mathrm{~g})$ and $\mathrm{NaCl}(1.1 \mathrm{~g})$ was finely ground under nitrogen atmosphere using a mortar and pestle, placed into a $50 \mathrm{ml}$ Airfree flask under nitrogen and melted at $180{ }^{\circ} \mathrm{C}$. A homogeneous mixture of 4-fluorophtalic anhydride $(800 \mathrm{mg}, 4.8 \mathrm{mmol})$, para-hydroquinone (600 mg, $5.4 \mathrm{mmol})$ and $\mathrm{AlCl}_{3}(2.6 \mathrm{~g})$ was added to the above melt, and the flask content was heated at $220{ }^{\circ} \mathrm{C}$ for $2 \mathrm{~h}$. The hot mixture was poured into crushed ice and $40 \mathrm{ml}$ of concentrated $\mathrm{HCl}$. The solid was collected by filtration, washed with water, and dried in vacuo. The crude intermediate product was dissolved in methanol, and $\mathrm{NaBH}_{4}(681 \mathrm{mg}, 18 \mathrm{mmol})$ was added in small portions to the solution upon cooling with an ice bath, and the resulting mixture was refluxed for $24 \mathrm{~h}$. After cooling, the reaction mixture was diluted with water $(60 \mathrm{ml})$ and acidified with concentrated $\mathrm{HCl}$. The precipitate was collected by filtration and dried in vacuo. The crude product was purified by column chromatography on silica gel (eluent hexanes $-\mathrm{CH}_{2} \mathrm{Cl}_{2}$ 1:2) to yield 598 $\mathrm{mg}(50 \%)$ of $\mathbf{S} 4$ as a brilliant orange solid, $R_{\mathrm{f}} 0.3$, mp. $239-240{ }^{\circ} \mathrm{C} .{ }^{1} \mathrm{H}$ NMR $(500 \mathrm{MHz}$, DMSOD6) $\delta 8.66(\mathrm{~s}, 1 \mathrm{H}), 8.60(\mathrm{~s}, 1 \mathrm{H}), 8.39\left(\mathrm{dd}, J_{1}=9.1, J_{2}=5.7 \mathrm{~Hz}, 1 \mathrm{H}\right), 8.10\left(\mathrm{dd}, J_{1}=9.9, J_{2}=2.7\right.$ $\mathrm{Hz}, 1 \mathrm{H}), 7.70$ (ddd, $\left.J_{1}=9.1, J_{2}=8.3, J_{3}=2.7 \mathrm{~Hz}, 1 \mathrm{H}\right), 7.16(\mathrm{~s}, 2 \mathrm{H}) .{ }^{19} \mathrm{~F}$ NMR $(471 \mathrm{MHz}$, DMSO$\mathrm{D}_{6},{ }^{1} \mathrm{H}$-decoupled) $\delta-108.54$ (s). HRMS (ESI-TOF) $m / z 249.0328[\mathrm{M}+\mathrm{Na}]^{+}$(calcd. for $\mathrm{C}_{14} \mathrm{H}_{7} \mathrm{FO}_{2}$ 249.0323). 
6-Fluoro-1,4-bis(trimethylsilylethynyl)anthracene (S5) was prepared following a literature procedure by Swager. ${ }^{4}$ A solution of BuLi in hexanes $(3.75 \mathrm{ml}$ of $1.6 \mathrm{M}$ solution, 6 mmol) was added dropwise upon stirring to a solution of $686 \mathrm{mg}$ (7 mmol) of trimethylsilylacetylene in $10 \mathrm{ml}$ of $\mathrm{THF}$ at $0^{\circ} \mathrm{C}$, and the reaction mixture was allowed to warm to room temperature. Compound S4 $(452.4 \mathrm{mg}, 1 \mathrm{mmol})$ was added in a single portion, and the reaction mixture was stirred for $12 \mathrm{~h}$ at room temperature. A saturated solution of $\mathrm{SnCl}_{2}$ in $10 \%$ $\mathrm{HCl}(20 \mathrm{ml})$ was added, and the reaction mixture was stirred for $1 \mathrm{~h}$, as the reaction progress was monitored by TLC (hexanes). Upon completion, the reaction mixture was partitioned between water and hexanes, organic layer was separated, washed with water, brine, dried over $\mathrm{Na}_{2} \mathrm{SO}_{4}$, and concentrated in vacuo. The crude product was purified by column chromatography on silica gel (eluent hexanes) to afford $502 \mathrm{mg}(64 \%)$ of $\mathbf{S 5}$ as a brilliant yellow solid, $R_{\mathrm{f}} 0.3, \mathrm{mp} .206-207^{\circ} \mathrm{C}$. ${ }^{1} \mathrm{H}$ NMR $\left(300 \mathrm{MHz}, \mathrm{CDCl}_{3}\right) \delta 8.89(\mathrm{~s}, 1 \mathrm{H}), 8.82(\mathrm{~s}, 1 \mathrm{H}), 8.08\left(\mathrm{dd}, J_{1}=9.3, J_{2}=5.7 \mathrm{~Hz}, 1 \mathrm{H}\right), 7.70$ $-7.59(\mathrm{~m}, 3 \mathrm{H}), 7.34\left(\mathrm{ddd}, J_{1}=9.3, J_{2}=8.3, J_{3}=2.5 \mathrm{~Hz}, 1 \mathrm{H}\right), 0.39(\mathrm{~s}, 18 \mathrm{H}) .{ }^{19} \mathrm{~F} \mathrm{NMR}(471 \mathrm{MHz}$, $\mathrm{CD}_{2} \mathrm{Cl}_{2},{ }^{1} \mathrm{H}$-decoupled) $\delta-112.93$ (s). HRMS (ESI-TOF) $m / z 411.1378[\mathrm{M}+\mathrm{Na}]^{+}$(calcd. for $\mathrm{C}_{24} \mathrm{H}_{25} \mathrm{FSi}_{2}$ 411.1377).

Compound S6. A mixture of $106 \mathrm{mg}(0.272 \mathrm{mmol})$ of compound S5 and $155 \mathrm{mg}(1.087$ mmol) of dimethyl acetylenedicarboxylate was heated at $140{ }^{\circ} \mathrm{C}$ for $24 \mathrm{~h}$. The crude product was purified by column chromatography on silica gel (eluent $\mathrm{CH}_{2} \mathrm{Cl}_{2}$ ) to afford $143 \mathrm{mg}(>99 \%)$ of S6 as a waxy beige solid, $R_{\mathrm{f}} 0.3 .{ }^{1} \mathrm{H} \mathrm{NMR}\left(500 \mathrm{MHz}, \mathrm{CDCl}_{3}\right) \delta 7.31\left(\mathrm{dd}, J_{1}=8.1, J_{2}=4.9 \mathrm{~Hz}, 1 \mathrm{H}\right)$, $7.12\left(\mathrm{dd}, J_{1}=8.0, J_{2}=2.5 \mathrm{~Hz}, 1 \mathrm{H}\right), 7.06(\mathrm{~s}, 2 \mathrm{H}), 6.75-6.70(\mathrm{~m}, 1 \mathrm{H}), 5.91(\mathrm{~s}, 1 \mathrm{H}), 5.90(\mathrm{~s}, 1 \mathrm{H})$, $3.81(\mathrm{~s}, 6 \mathrm{H}), 0.34(\mathrm{~s}, 9 \mathrm{H}), 0.33(\mathrm{~s}, 9 \mathrm{H}) .{ }^{19} \mathrm{~F} \mathrm{NMR}$ (282 MHz, $\mathrm{CDCl}_{3},{ }^{1} \mathrm{H}$-decoupled) $\delta-116.68$ (s). HRMS (ESI-TOF) $m / z 531.1835[\mathrm{M}+\mathrm{H}]^{+}$(calcd. for $\mathrm{C}_{30} \mathrm{H}_{31} \mathrm{FO}_{4} \mathrm{Si}_{2}$ 531.1823).

Compound S7. A solution of Bu4NF in THF (90 $\mu$ l of $1 \mathrm{M}$ solution, $0.09 \mathrm{mmol}$ ) was added to a stirred solution of $143 \mathrm{mg}(0.27 \mathrm{mmol})$ of $\mathbf{S 6}$ in $2.7 \mathrm{ml}$ of THF, and the reaction mixture was stirred at room temperature for $30 \mathrm{~min}$. Then the reaction mixture was quenched with water $(15 \mathrm{ml})$, and extracted with diethyl ether. Organic layers were separated, washed with water, brine, dried over $\mathrm{Na}_{2} \mathrm{SO}_{4}$, and concentrated in vacuo. The crude product was purified by column chromatography on silica gel (eluent $\mathrm{CH}_{2} \mathrm{Cl}_{2}$ - hexanes 2:1) to afford $101 \mathrm{mg}(98 \%)$ of $\mathbf{S} 7$ as a yellowish foamy solid, $R_{\mathrm{f}} 0.3$, mp. $121-123{ }^{\circ} \mathrm{C} .{ }^{1} \mathrm{H}$ NMR $\left(300 \mathrm{MHz}, \mathrm{CD}_{2} \mathrm{Cl}_{2}\right) \delta 7.38\left(\mathrm{dd}, J_{1}=8.1\right.$, $\left.J_{2}=5.0 \mathrm{~Hz}, 1 \mathrm{H}\right), 7.20\left(\mathrm{dd}, J_{1}=8.0, J_{2}=2.5 \mathrm{~Hz}, 1 \mathrm{H}\right), 7.15(\mathrm{~s}, 2 \mathrm{H}), 6.77\left(\mathrm{ddd}, J_{1}=9.2, J_{2}=8.1, J_{3}\right.$ 
$=2.5 \mathrm{~Hz}, 1 \mathrm{H}), 5.94(\mathrm{~s}, 2 \mathrm{H}), 3.78(\mathrm{~s}, 6 \mathrm{H}), 3.51(\mathrm{~s}, 2 \mathrm{H}) .{ }^{19} \mathrm{~F}$ NMR $\left(471 \mathrm{MHz}, \mathrm{CD}_{2} \mathrm{Cl}_{2},{ }^{1} \mathrm{H}\right.$-decoupled $)$ $\delta-117.06$ (s). HRMS (ESI-TOF) $m / z 387.1039[\mathrm{M}+\mathrm{H}]^{+}$(calcd. for $\mathrm{C}_{24} \mathrm{H}_{15} \mathrm{FO}_{4} 387.1033$ ).

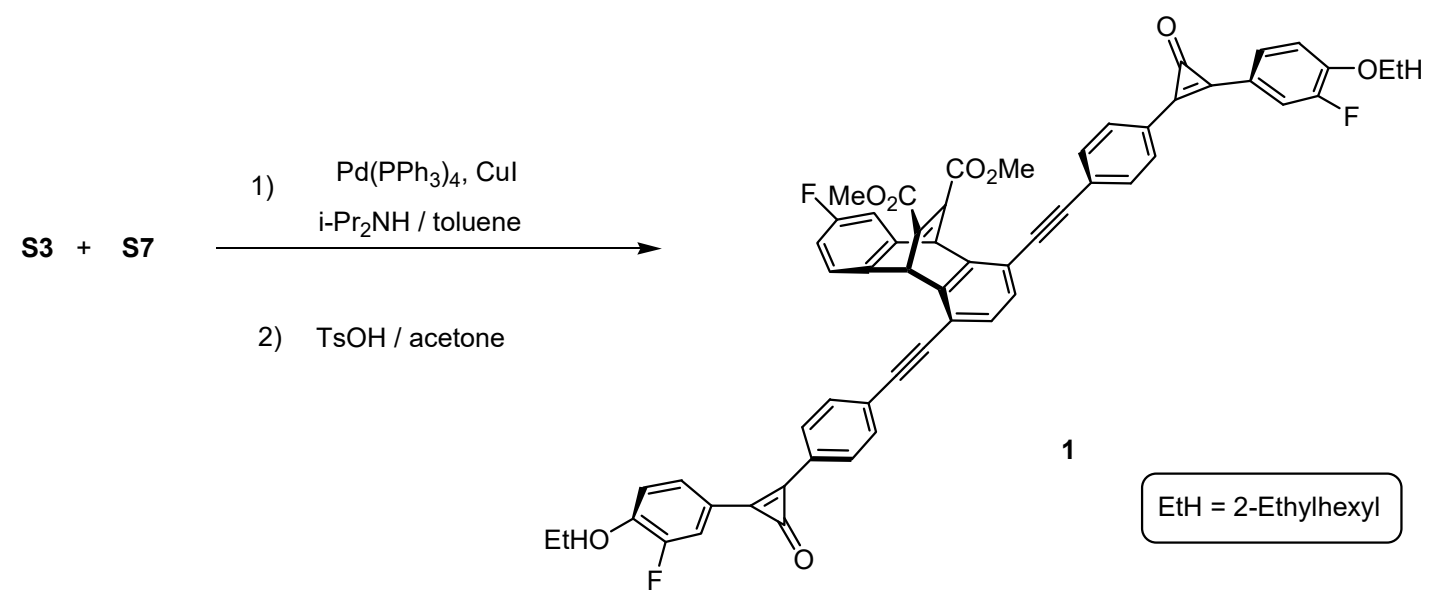

Compound 1 was synthesized in nitrogen atmosphere in a glovebox. A mixture of 56.5 $\mathrm{mg}(0.1 \mathrm{mmol})$ of $\mathbf{S 3}, 19.3 \mathrm{mg}(0.05 \mathrm{mmol})$ of $\mathbf{S} 7,3.0 \mathrm{mg}(2.5 \mu \mathrm{mol}, 5 \mathrm{~mol} \%)$ of $\mathrm{Pd}\left(\mathrm{PPh}_{3}\right) 4$ in 1 $\mathrm{ml}$ of a mixture of toluene - diisopropylamine (7:3) was stirred for $2 \mathrm{~min}$ at room temperature, followed by addition of a trace amount $(\sim 0.25 \mathrm{mg})$ of CuI. The reaction mixture was stirred at room temperature for $12 \mathrm{~h}$, and concentrated in vacuo. The residue was dissolved in acetone, and a small crystal of para-toluenesulfonic acid was added, and the reaction mixture was stirred at room temperature for $30 \mathrm{~min}$. After concentration in vacuo, the crude product was purified by column chromatography on silica gel (eluent $\mathrm{CH}_{2} \mathrm{Cl}_{2}-\mathrm{MeOH} 50: 1$ ) to afford $52.5 \mathrm{mg}$ (96\%) of 1 as a bright yellow solid, $R_{\mathrm{f}} 0.3$, mp. $231-233{ }^{\circ} \mathrm{C}$ (dec.). ${ }^{1} \mathrm{H}$ NMR $\left(300 \mathrm{MHz}, \mathrm{CD}_{2} \mathrm{Cl}_{2}\right) \delta 7.99(\mathrm{~d}, J$ $=8.9 \mathrm{~Hz}, 4 \mathrm{H}), 7.85(\mathrm{~d}, J=8.9 \mathrm{~Hz}, 4 \mathrm{H}), 7.78(\mathrm{~d}, J=7.8 \mathrm{~Hz}, 2 \mathrm{H}), 7.72(\mathrm{~d}, J=11.8 \mathrm{~Hz}, 2 \mathrm{H}), 7.47$ $\left(\mathrm{dd}, J_{1}=8.5, J_{2}=4.9 \mathrm{~Hz}, 1 \mathrm{H}\right), 7.34-7.24(\mathrm{~m}, 3 \mathrm{H}), 7.19(\mathrm{t}, J=7.8 \mathrm{~Hz}, 2 \mathrm{H}), 6.87-6.76(\mathrm{~m}, 1 \mathrm{H}), 6.07$ (s, 2H), 4.05 (d, $J=6.0 \mathrm{~Hz}, 4 \mathrm{H}), 3.82$ (s, 6H), 1.83 (septet, $J=6.0 \mathrm{~Hz}, 2 \mathrm{H}), 1.63-1.23$ (m, 16H), $1.03-0.80(\mathrm{~m}, 12 \mathrm{H}) .{ }^{19} \mathrm{~F}$ NMR (471 MHz, $\mathrm{CD}_{2} \mathrm{Cl}_{2},{ }^{1} \mathrm{H}$-decoupled) $\delta-116.96(\mathrm{~s}, 1 \mathrm{~F}),-133.34$ (s, 2F). HRMS (ESI-TOF) $m / z$ 1109.4241 [M+Na] $]^{+}$(calcd. for $\mathrm{C}_{70} \mathrm{H}_{61} \mathrm{~F}_{3} \mathrm{O}_{8}$ 1109.4217).

Computational studies. DFT computations were carried out using Gaussian 16 computational package running on a Windows-based computer. ${ }^{5}$ Geometry optimization of a truncated compound 1 (2-ethylhexyl substituents replaced with methyl groups) was carried out at a 
B3LYP/6-31G* level with CPCM solvation treatment (solvent acetonitrile), and frequency analysis was performed on the optimized structure to check for a true minimum. Subsequent timedependent DFT single-point computations at the same level of theory were done on the optimized structure to identify 6 lowest-energy singlet vertical (Franck-Condon) excited states. The obtained geometry, molecular orbitals, and transition dipole moments were visualized using GaussView program. ${ }^{6}$

\section{Photochemistry of 1 in isotropic solution.}

Preparative photolysis. A solution of $1(10.9 \mathrm{mg}, 0.01 \mathrm{mmol})$ in $5 \mathrm{ml}$ of THF was placed in a Pyrex round-bottom flask, and irradiated with a handheld UV lamp $(\lambda=365 \mathrm{~nm})$ at room temperature for $40 \mathrm{~min}$ upon gentle nitrogen bubbling. Upon completion of irradiation, the reaction mixture was concentrated in vacuo. The crude product was purified by column chromatography on silica gel (eluent hexanes $-\mathrm{CH}_{2} \mathrm{Cl}_{2}$ 1:1) to afford $8.8 \mathrm{mg}$ (96\%) of photoproduct 3 as a yellow solid, $R_{\mathrm{f}} 0.3$, mp. $184-185{ }^{\circ} \mathrm{C} .{ }^{1} \mathrm{H}$ NMR $\left(500 \mathrm{MHz}, \mathrm{CDCl}_{3}\right) \delta$ 7.63-7.58 (m, 4H), 7.57-7.53 (m, $4 \mathrm{H}), 7.40\left(\mathrm{dd}, J_{1}=8.1, J_{2}=4.9 \mathrm{~Hz}, 1 \mathrm{H}\right), 7.30-7.25(\mathrm{~m}, 4 \mathrm{H}$, the area is obscured by the solvent residual signal), 7.24-7.19 (m, 3H), $6.94(\mathrm{t}, J=8.5 \mathrm{~Hz}, 2 \mathrm{H}), 6.75\left(\mathrm{ddd}, J_{1}=8.9, J_{2}=8.1, J_{3}=2.5\right.$ $\mathrm{Hz}, 1 \mathrm{H}), 6.02$ (s, 2H), 3.95 (d, $J=6.0 \mathrm{~Hz}, 2 \mathrm{H}), 3.94$ (d, $J=6.0 \mathrm{~Hz}, 2 \mathrm{H}$ ), 3.83 (s, 6H), 1.79 (septet, $J=6.0 \mathrm{~Hz}, 2 \mathrm{H}), 1.55-1.39(\mathrm{~m}, 8 \mathrm{H}), 1.36-1.27(\mathrm{~m}, 8 \mathrm{H}), 0.99-0.89(\mathrm{~m}, 12 \mathrm{H}) .{ }^{19} \mathrm{~F}$ NMR $(471$ $\mathrm{MHz}, \mathrm{CD}_{2} \mathrm{Cl}_{2},{ }^{1} \mathrm{H}$-decoupled) $\delta-116.42$ (s), -133.97 (s), -133.98 (s). HRMS (ESI-TOF) $\mathrm{m} / \mathrm{z}$ $1053.4227[\mathrm{M}+\mathrm{Na}]^{+}$(calcd. for $\mathrm{C}_{68} \mathrm{H}_{61} \mathrm{~F}_{3} \mathrm{O}_{6}$ 1053.4318).

Exploratory photolysis. A photochemical setup described below for teh studies in LC media was used, but without the polarizer. A solution of 1 in THF (conc. $1 \mathrm{mg} \mathrm{ml}^{-1}, 10 \mathrm{ml}$ ) was irradiated in a Pyrex round-bottom flask at room temperature upon gentle nitrogen bubbling for $4.5 \mathrm{~h}$ ( $\lambda 370$ $\mathrm{nm}$, incident light optical power $100 \mu \mathrm{W} \mathrm{cm}{ }^{-2}$ ). Samples were withdrawn after specified periods, concentrated in vacuo and analyzed by ${ }^{19} \mathrm{~F}$ NMR spectroscopy. The results of the study are shown in Table S1. 
Table S1. Photolysis of 1 in THF Solution ${ }^{a}$

\begin{tabular}{lll}
\hline $\begin{array}{l}\text { Irradiation } \\
\text { time }(\mathrm{min})\end{array}$ & $\begin{array}{l}\text { Total conversion } \\
(\%)^{b}\end{array}$ & $\begin{array}{l}\text { Ratio of product } \\
\mathbf{3} \text { to product } \mathbf{2}^{b}\end{array}$ \\
\hline 10 & 4 & only $\mathbf{2}$ \\
20 & 9 & $1: 9$ \\
40 & 15 & $1: 2$ \\
60 & 25 & $1: 1.75$ \\
100 & 44 & $1: 1.08$ \\
140 & 74 & $1: 0.58$ \\
220 & 89 & $1: 0.33$ \\
270 & 100 & only $\mathbf{3}$ \\
\hline
\end{tabular}

${ }^{a}$ Irradiation was carried out on a solution of 1 in THF (conc. $1 \mathrm{mg} \mathrm{ml}^{-1}$ ) at room temperature, using light power density $100 \mu \mathrm{W} \mathrm{cm}{ }^{-2}$, in nitrogen atmosphere. ${ }^{b}$ Determined using ${ }^{19} \mathrm{~F}$ NMR spectroscopy.

\section{Photochemistry of 1 in nematic liquid crystalline phase with plane-polarized light.}

The experimental setup to carry out photochemical studies (Figure S3A) consisted of connected in line Newport 66353 300W Xe lamp, equipped with a 71445 electronic shutter controlled by a Newport 68945 digital exposure controller, Newport 61945 water-cooled liquid filter (filled with water), an iris diaphragm, Newport 77250 high throughput monochromator with manually-controlled slits, and a Thorlabs WP25M-UB wire-grid polarizer. A sample was mounted in a specially fabricated holder that could be rotated with respect to the incident light polarization plane. The optical power of incident light was measured with a Newport 70260 radiant power meter. The sample temperature was maintained at $\sim 40{ }^{\circ} \mathrm{C}$ using a small place heater.

Fabrication of $\mathbf{L C}$ cell and sample preparation. Quartz disks (25.4 mm diameter, 1.7 mm thickness, purchased from Chemglass Life Sciences) were ultrasonicated sequentially for 10 min in acetone, chloroform, methanol, and deionized water. The pre-cleaned disks were placed into Piranha solution (a mixture of conc. $\mathrm{H}_{2} \mathrm{SO}_{4}$ and $30 \% \mathrm{H}_{2} \mathrm{O}_{2}(7: 3)$ ) and ultrasonicated for 30 min. After rinsing with copious amount of deionized water, the disks were dried in $\mathrm{N}_{2}$ flow at room 
temperature for $12 \mathrm{~h}$. (NOTE: extreme care must be taken when dealing with piranha solutions as they can detonate when contacted with organic compounds!) A 2 wt. \% solution of poly(pyromellitic dianhydride-co-4,4'-oxydianiline) in cyclopentanone was spin-coated onto the pre-cleaned quartz discs at $2000 \mathrm{rpm}$ for $1 \mathrm{~min}$ (using Laurell WS-400A spin processor). The coated disks were baked at $100^{\circ} \mathrm{C}$ for $2 \mathrm{~h}$, and cured at $200{ }^{\circ} \mathrm{C}$ for additional $2 \mathrm{~h}$ on a hotplate in $\mathrm{N}_{2}$ atmosphere inside a glovebox to form a thin film of polyimide. The thickness of the film was 60-80 $\mathrm{nm}$ (as determined by scratching the film surface with a razor blade, and acquiring an acrossthe-scratch depth profile using Bruker Dektak XT stylus profiler). Then, the films were rubbed unidirectionally using a rotating rubber drum $(75 \mathrm{~mm}$ diameter, $75 \mathrm{~mm}$ length) wrapped with a velvet cloth. This produced parallel aligning grooves on the polyimide coating. A sandwich type LC cell with a $20 \mu \mathrm{m}$ gap was made by attaching a self-adhesive Kapton ring gasket $(20 \mu \mathrm{m}$ thickness) to one of the disks, placing a proper amount of $0.25 \mathrm{wt} . \%$ of 1 in $5 \mathrm{PCH}$ (heated to stay in isotropic phase), and carefully (to avoid formation of air bubbles in the LC layer) placing a second disk on top in such a way that the rubbing directions of both disks were parallel to each other (Figure S3B). The sandwiched cell was placed inside a Newport 883-OH optic holder and tightened with the holder's threaded internal ring to seal the cell against leaking (Figure S3C). To increase alignment of the photoactive compound $\mathbf{1}$, the complete assembled cell was placed in an oven at $65^{\circ} \mathrm{C}$ and kept there for $10 \mathrm{~min}$, then removed from the oven and allowed to cool to 40 ${ }^{\circ} \mathrm{C}$. This procedure was repeated 2 more times. The alignment of $\mathbf{1}$ in nematic LC phase was measured using polarization UV/vis spectroscopy before and after photoirradiation.

Photochemistry in nematic LC phase. A prepared sample was attached to a holder and irradiated at $370 \mathrm{~nm}$ at a specific angle $\theta$ between the polarization plane of incident light and the LC director for $10 \mathrm{~min}$ (incident light optical power $100 \mu \mathrm{W} \mathrm{cm}{ }^{-2}$, cell temperature $\sim 40^{\circ} \mathrm{C}$ ). After irradiation, the $\mathrm{LC}$ cell was disassembled, and the entire cell content was rinsed with $\mathrm{CH}_{2} \mathrm{Cl}_{2}$ into a round-bottom flask, and concentrated in vacuo. The LC solution was then used to prepare an NMR sample in $\mathrm{CDCl}_{3} .{ }^{19} \mathrm{~F}$ NMR spectra were acquired at $471 \mathrm{MHz}$, within a narrow chemical shift range $(\delta-75 \div-175 \mathrm{ppm})$; obtaining a satisfactory signal-to-noise ratio suitable for quantification required 16,384 scans. Note: After rinsing with $\mathrm{CH}_{2} \mathrm{Cl}_{2}$, the disks could be reused 3-4 times without degradation of their alignment surfaces. 


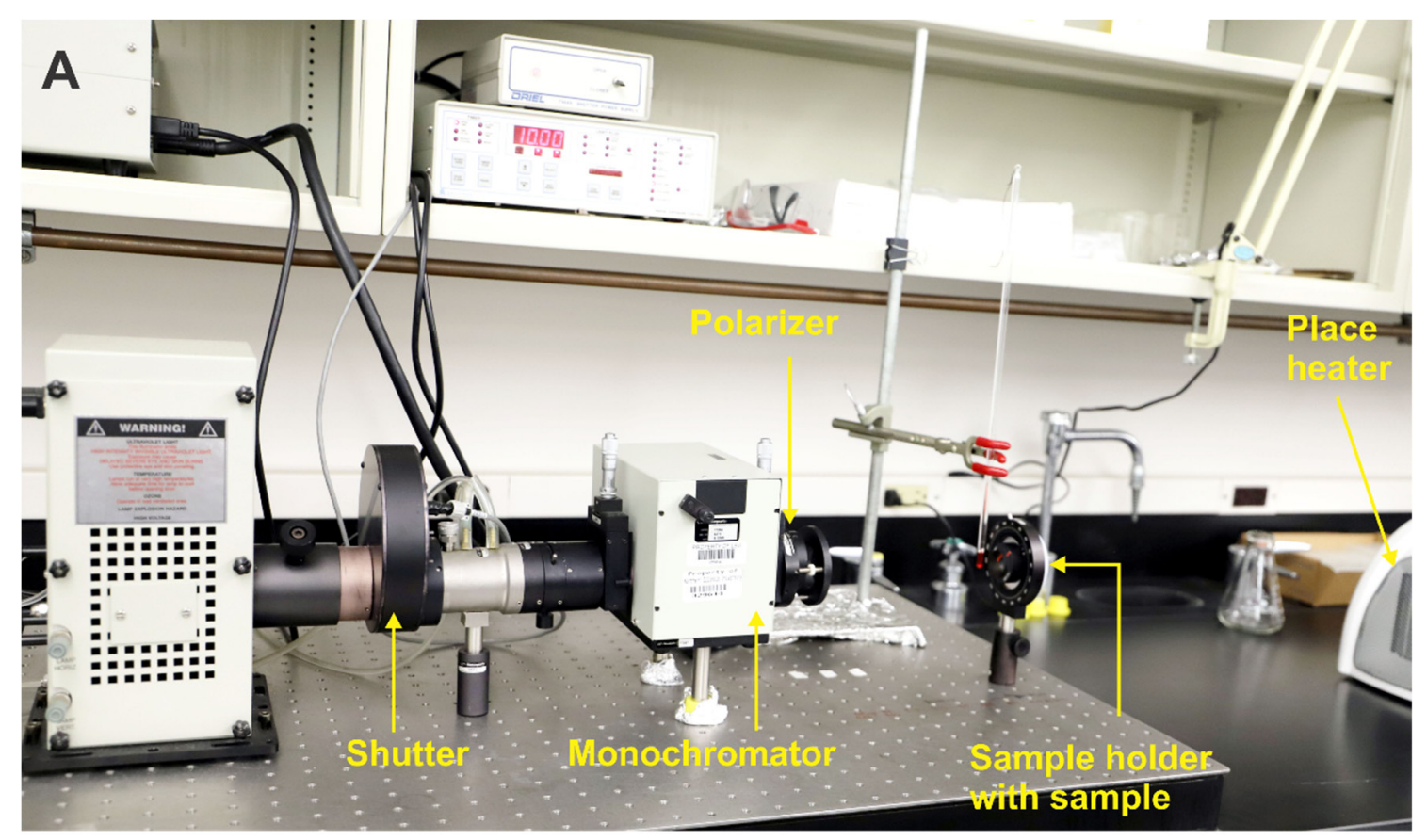

B
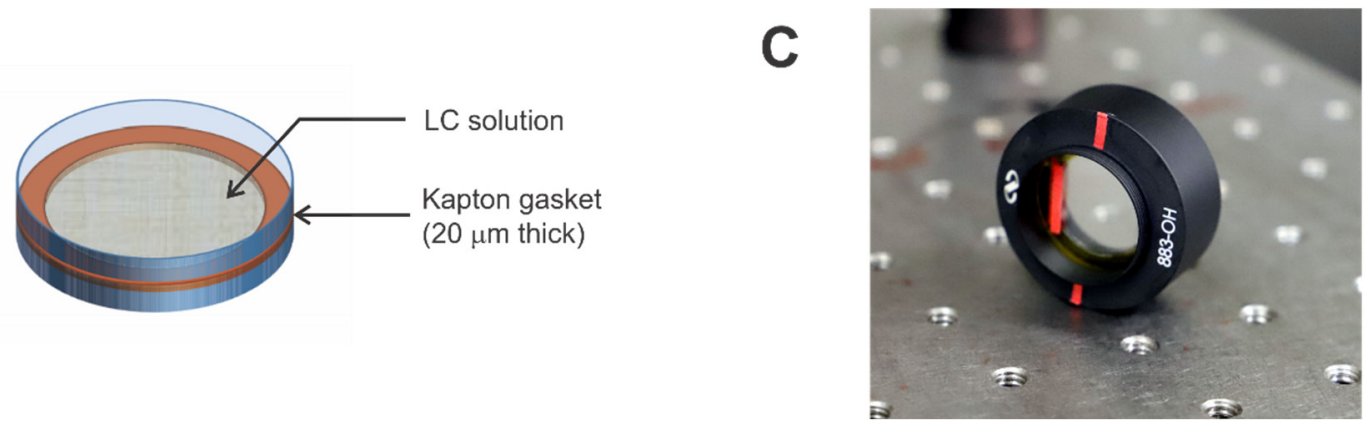

Figure S3. (A) Experimental setup for performing photochemical studies in nematic LC medium. (B) Schematic diagram of a preparative LC cell. (C) Assembled LC cell placed inside an optic holder. 
III. NMR Spectra

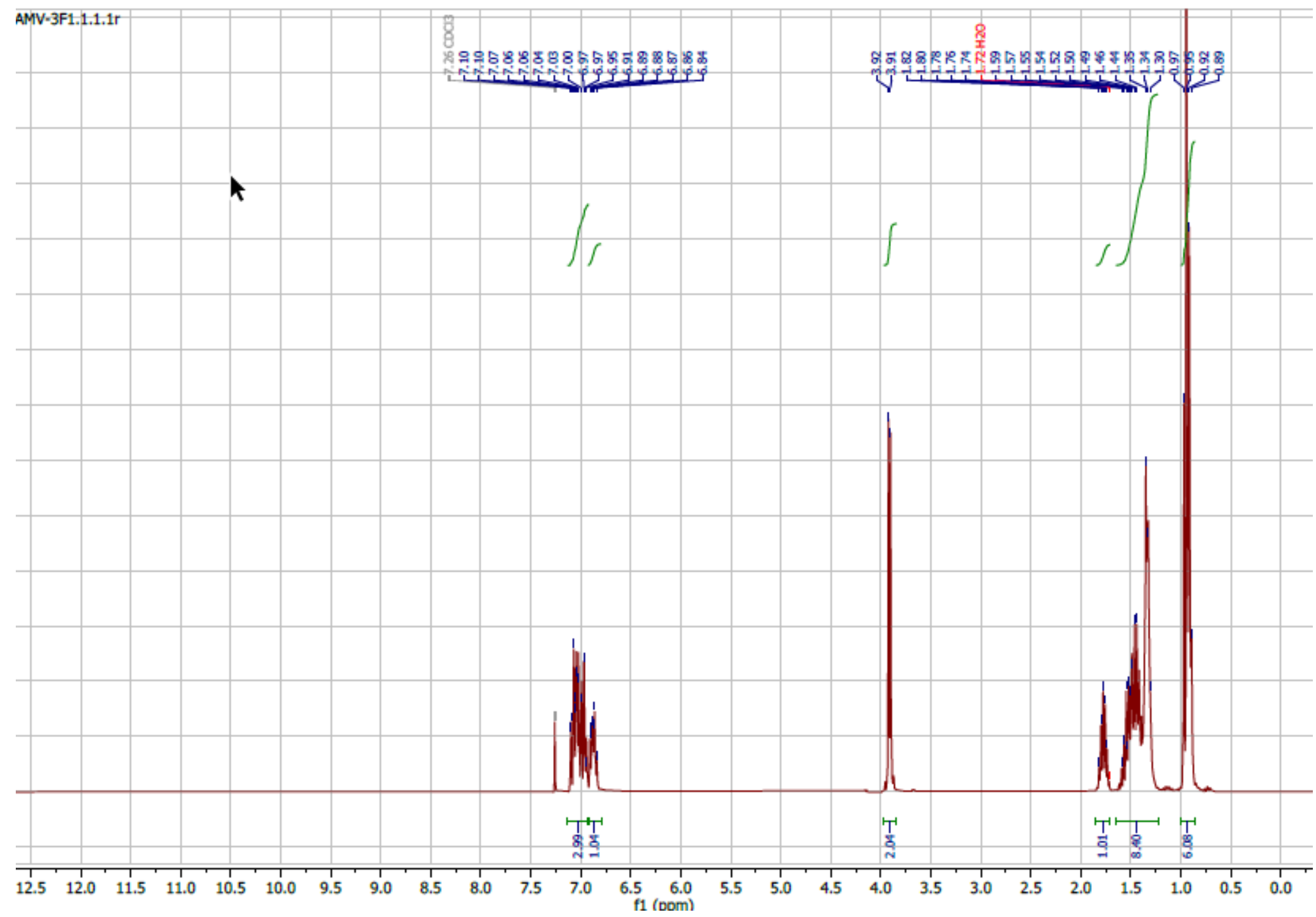

Figure S4. ${ }^{1} \mathrm{H}$ NMR spectrum $\left(300 \mathrm{MHz}, \mathrm{CDCl}_{3}\right)$ of compound $\mathbf{S 1}$. 


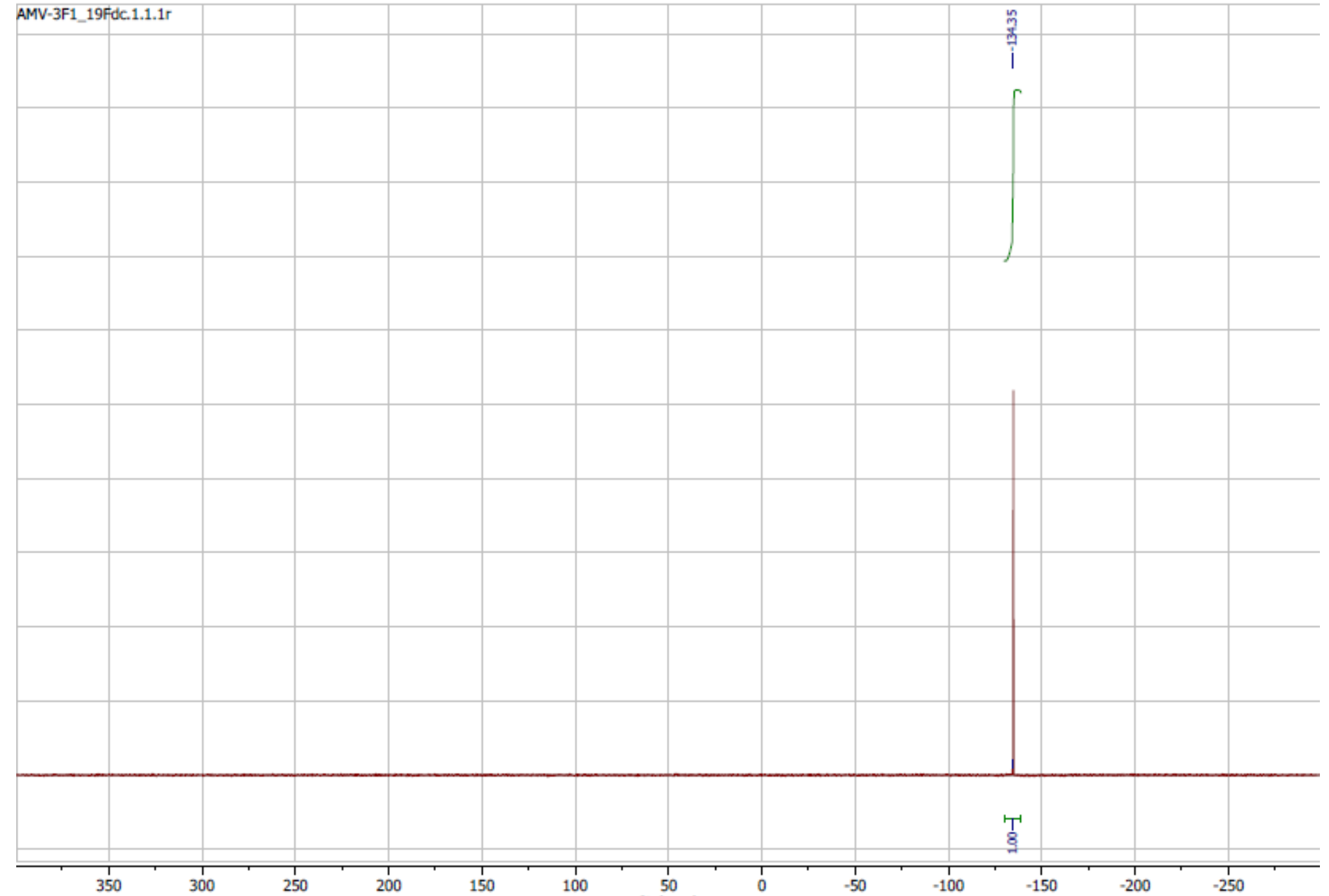

Figure S5. ${ }^{19} \mathrm{~F}$ NMR spectrum $\left(282 \mathrm{MHz}, \mathrm{CDCl}_{3}\right)$ of compound $\mathbf{S 1}$. 


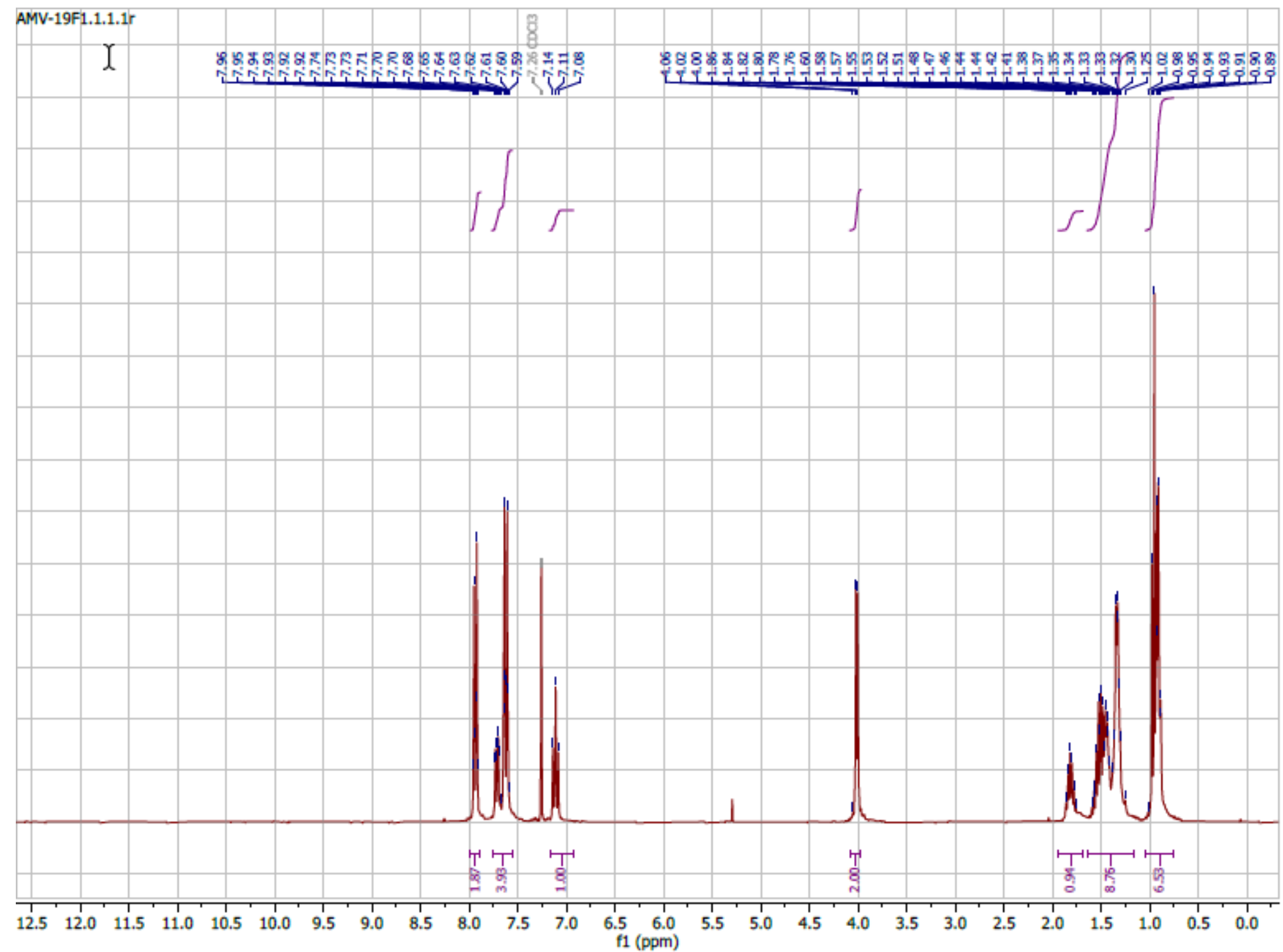

Figure S6. ${ }^{1} \mathrm{H}$ NMR spectrum $\left(300 \mathrm{MHz}, \mathrm{CDCl}_{3}\right)$ of compound $\mathbf{S 2}$. 


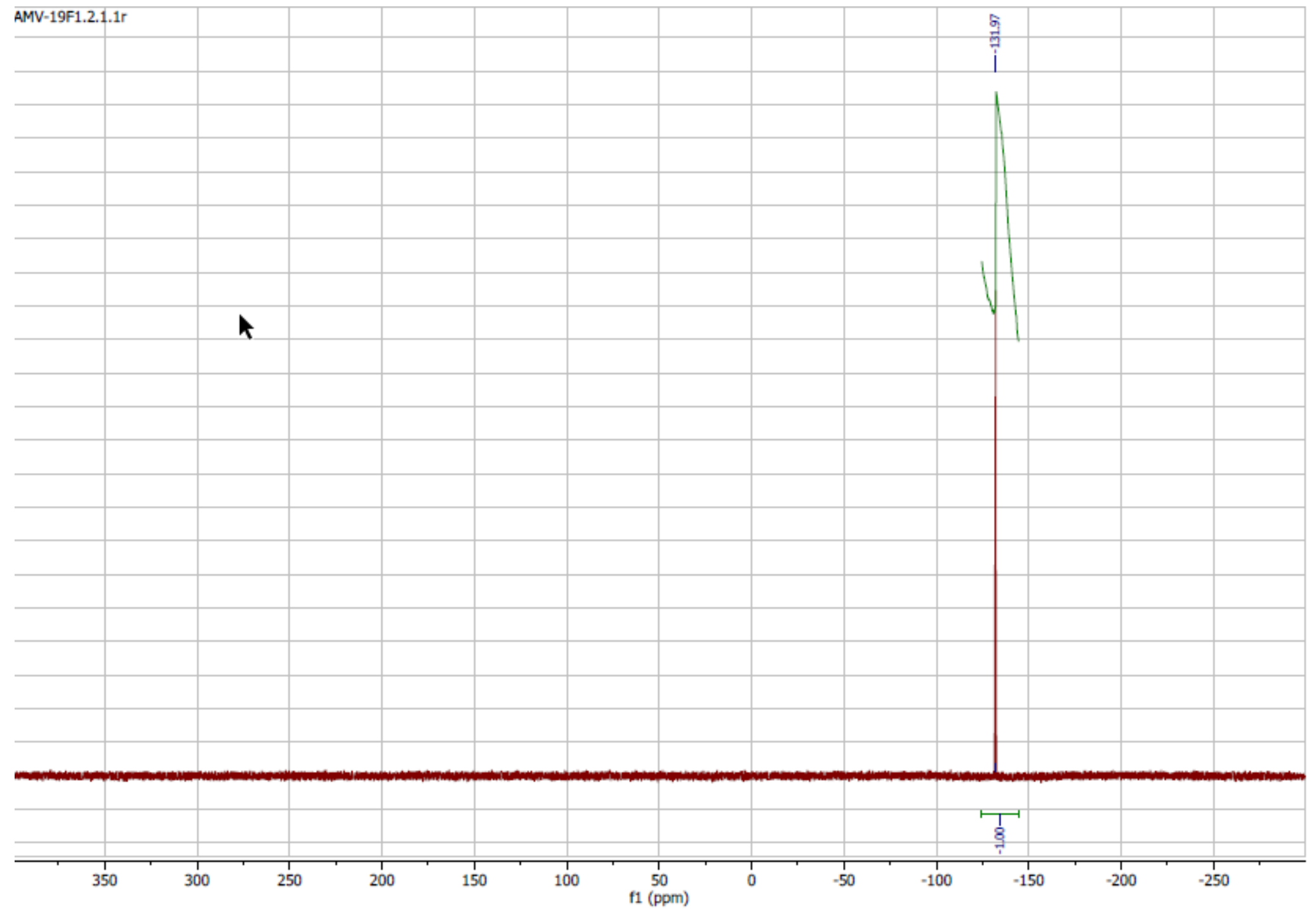

Figure S7. ${ }^{19} \mathrm{~F}$ NMR spectrum $\left(282 \mathrm{MHz}, \mathrm{CDCl}_{3}\right)$ of compound $\mathbf{S 2}$. 


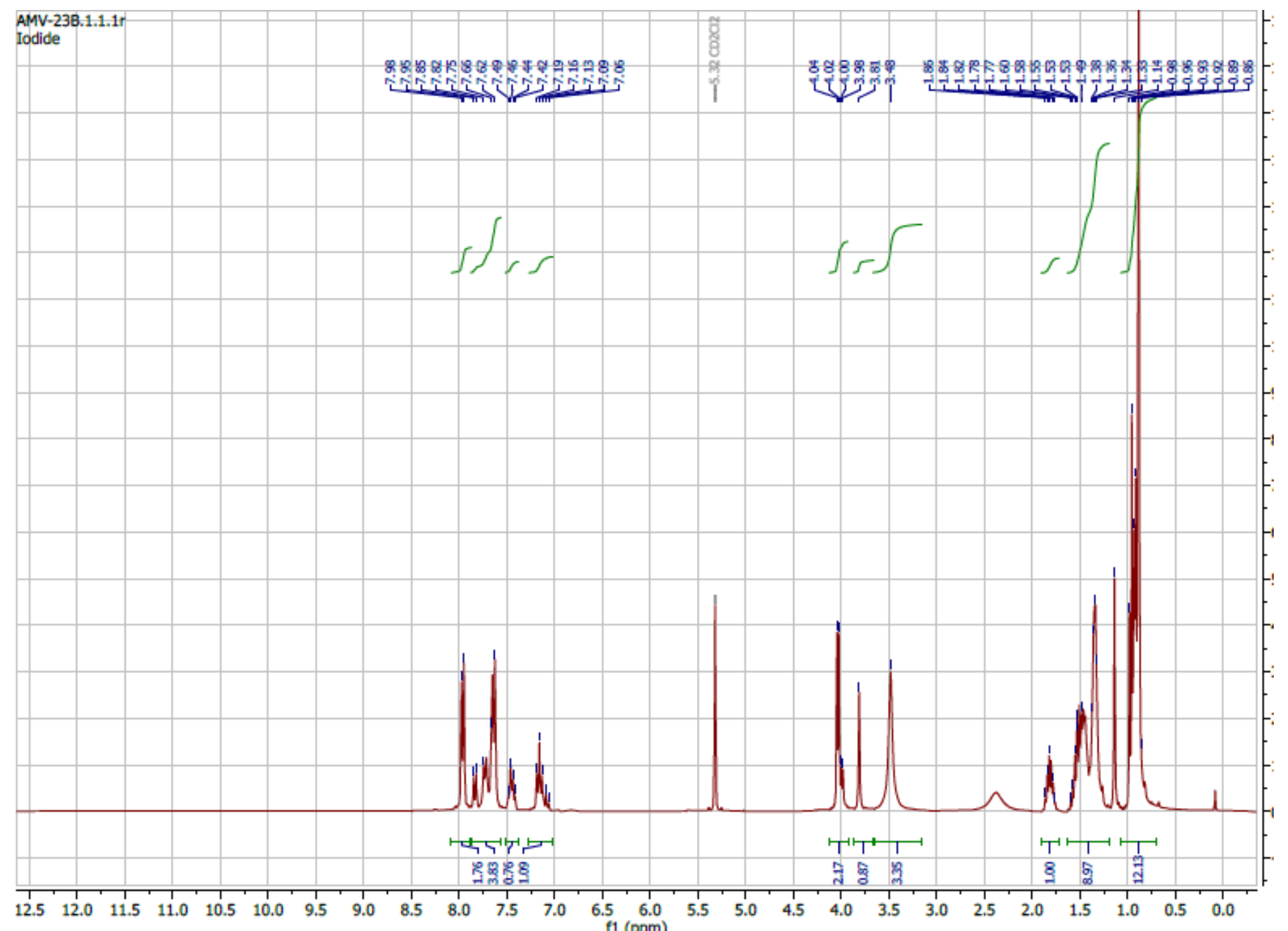

Figure S8. ${ }^{1} \mathrm{H}$ NMR spectrum $\left(300 \mathrm{MHz}, \mathrm{CD}_{2} \mathrm{Cl}_{2}\right)$ of compound $\mathbf{S 3}$. 


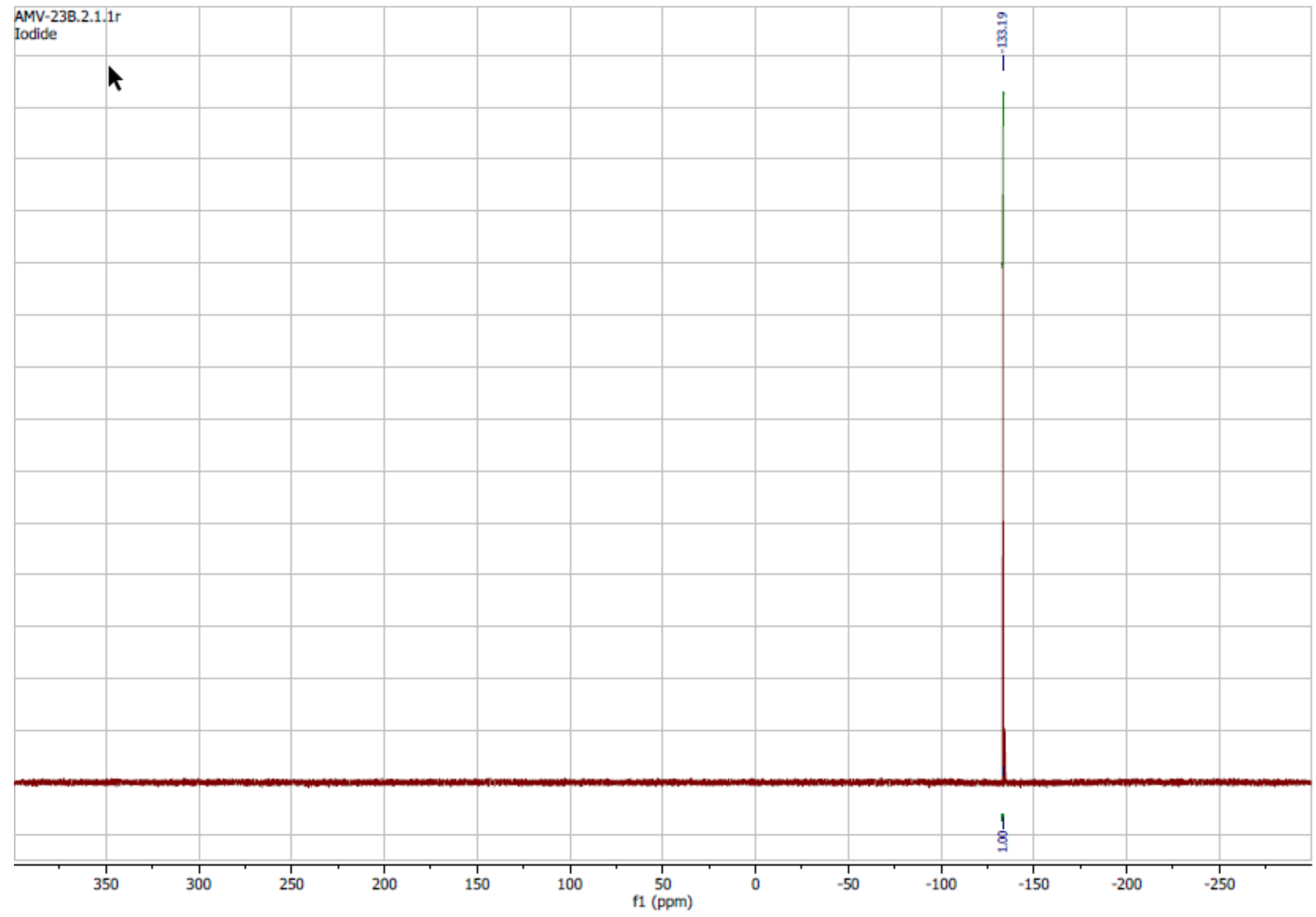

Figure S9. ${ }^{19} \mathrm{~F}$ NMR spectrum $\left(282 \mathrm{MHz}, \mathrm{CD}_{2} \mathrm{Cl}_{2}\right)$ of compound $\mathbf{S 3}$. 


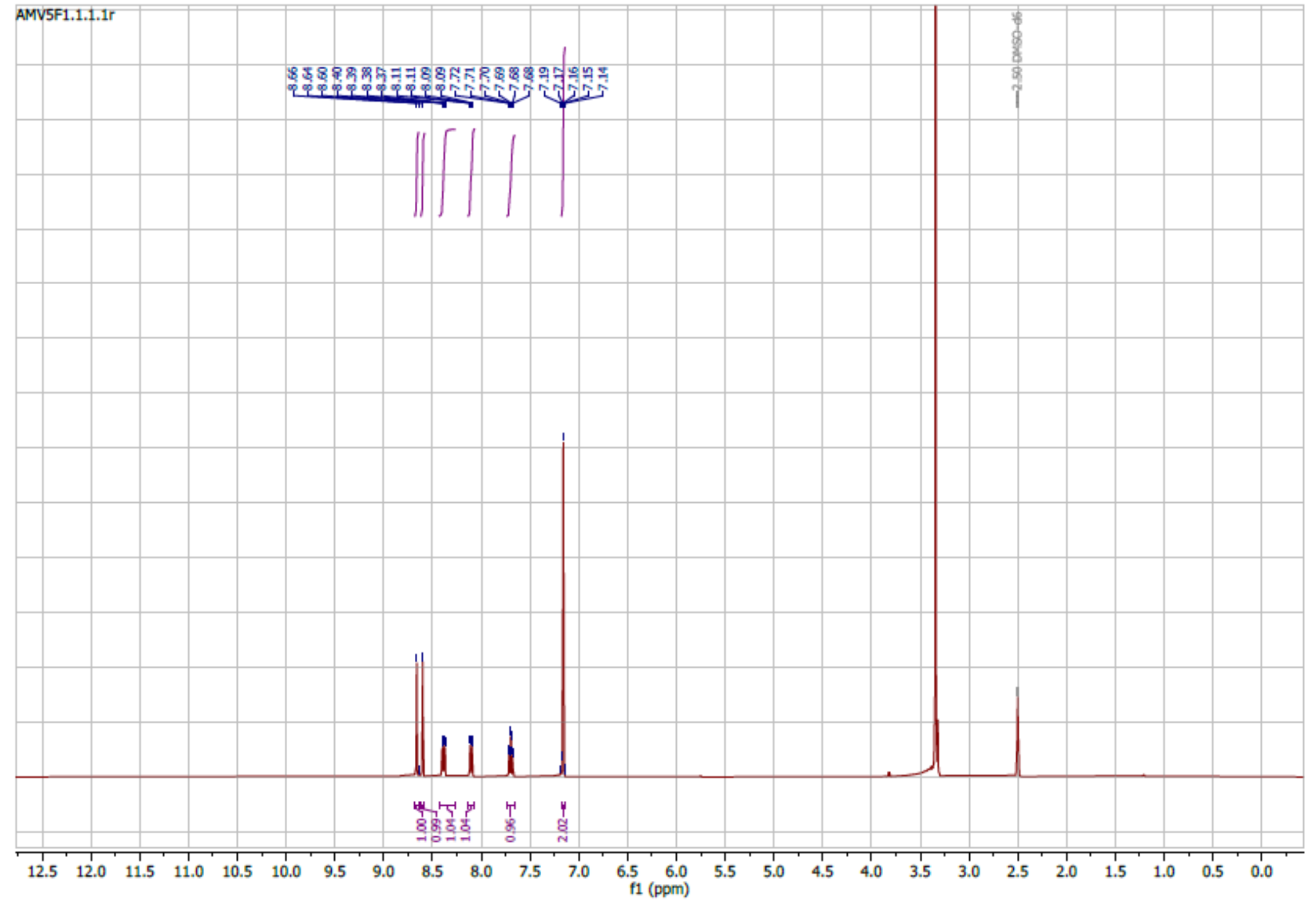

Figure S10. ${ }^{1} \mathrm{H}$ NMR spectrum (500 MHz, DMSO-D6) of compound S4. 


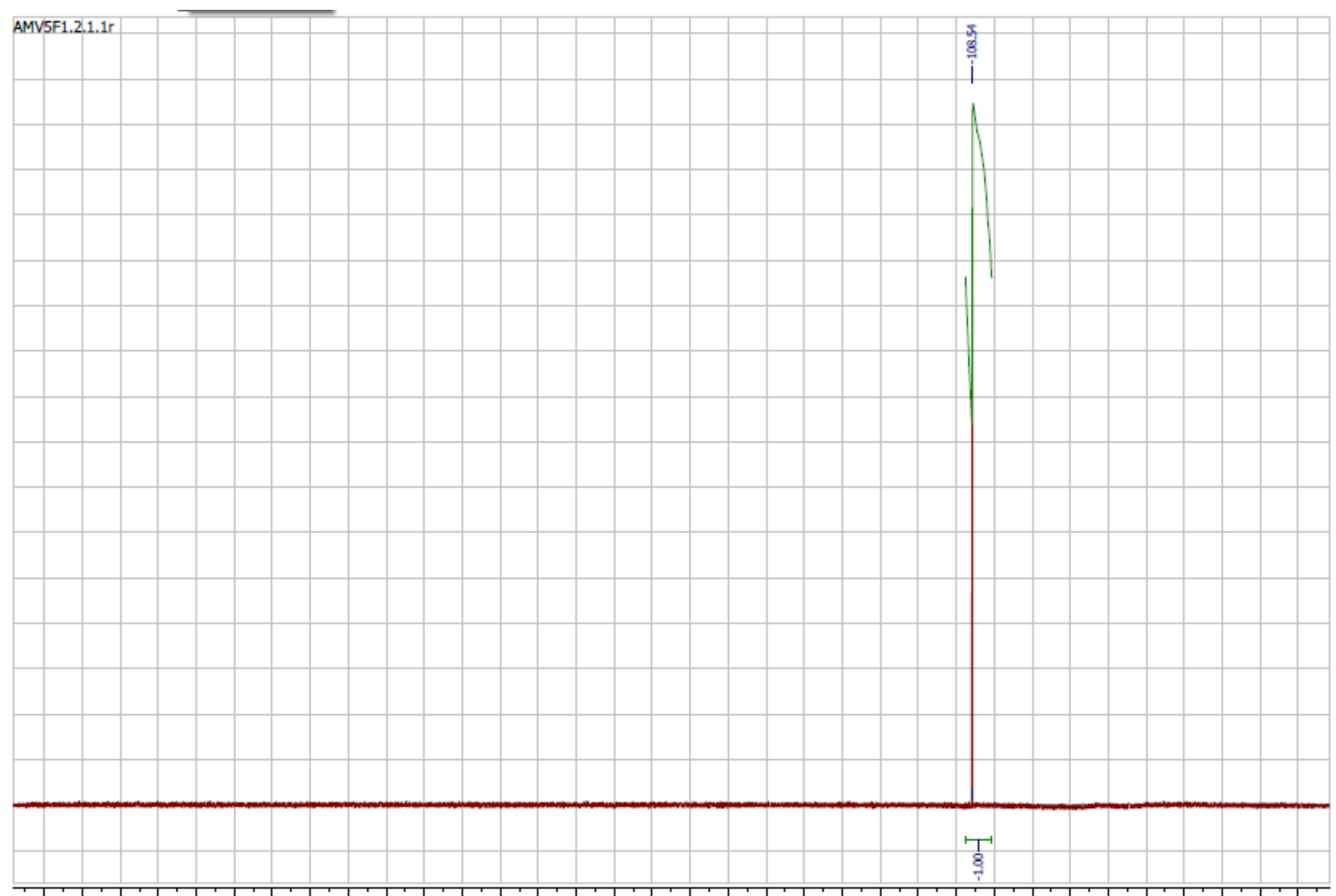

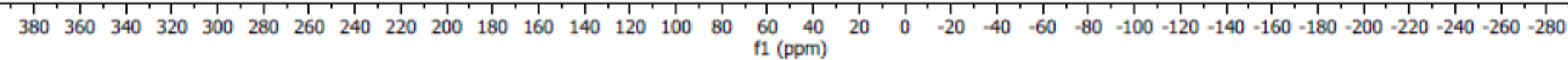

Figure S11. ${ }^{19} \mathrm{~F}$ NMR spectrum (471 MHz, DMSO-D6) of compound S4. 


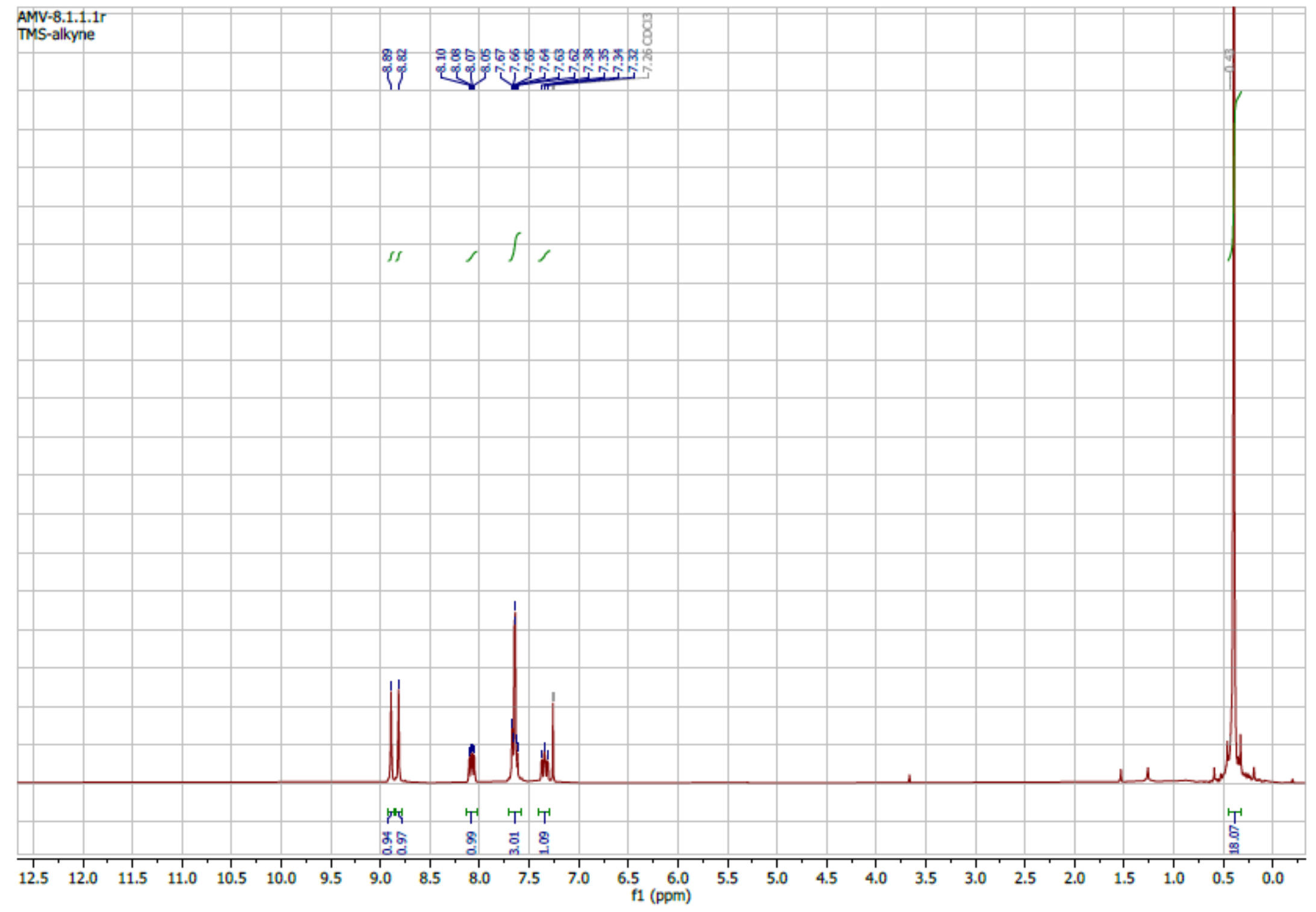

Figure S12. ${ }^{1} \mathrm{H}$ NMR spectrum $\left(300 \mathrm{MHz}, \mathrm{CDCl}_{3}\right)$ of compound $\mathbf{S 5}$. 


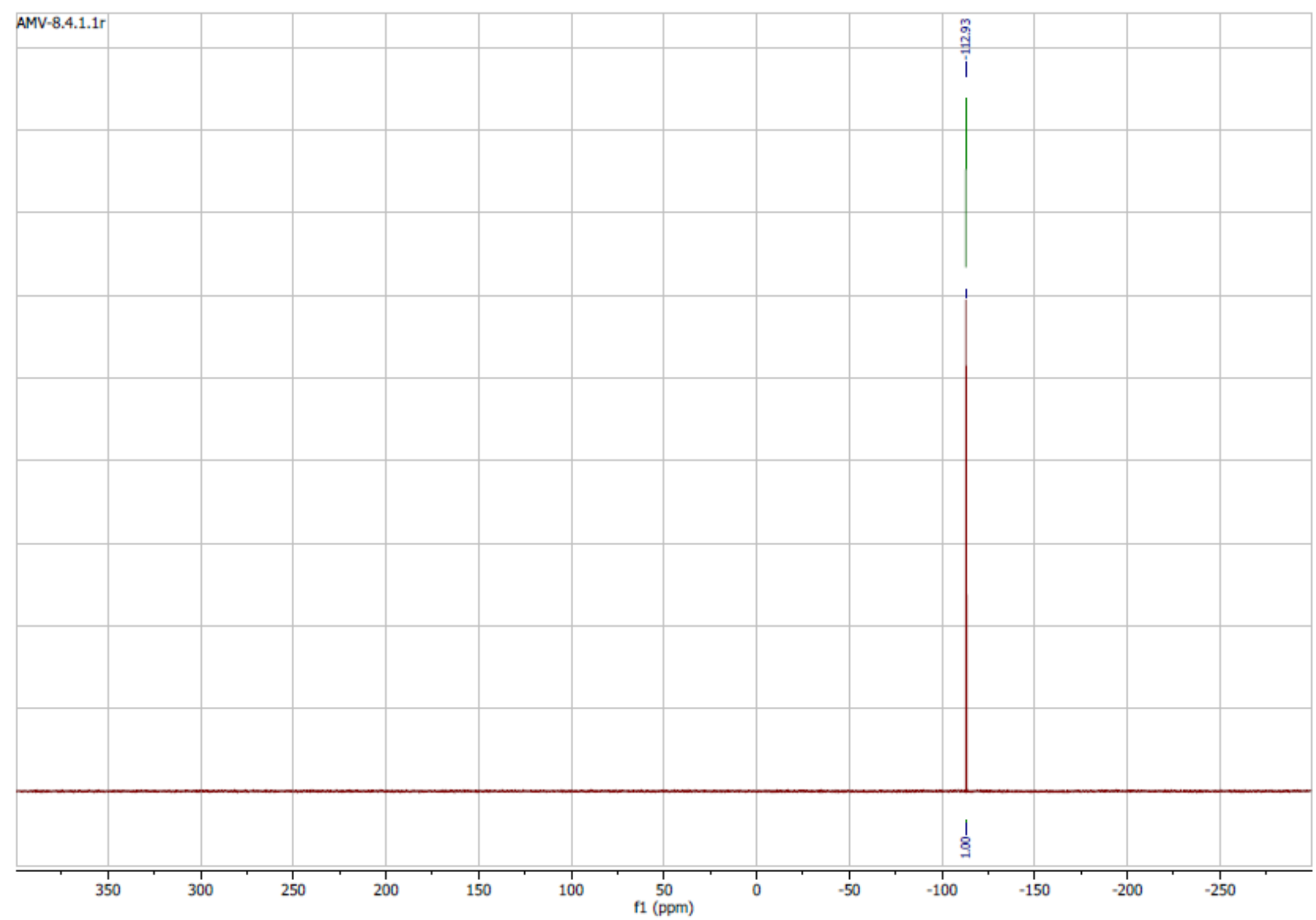

Figure S13. ${ }^{19} \mathrm{~F}$ NMR spectrum $\left(471 \mathrm{MHz}, \mathrm{CD}_{2} \mathrm{Cl}_{2}\right.$ ) of compound $\mathbf{S 5}$. 


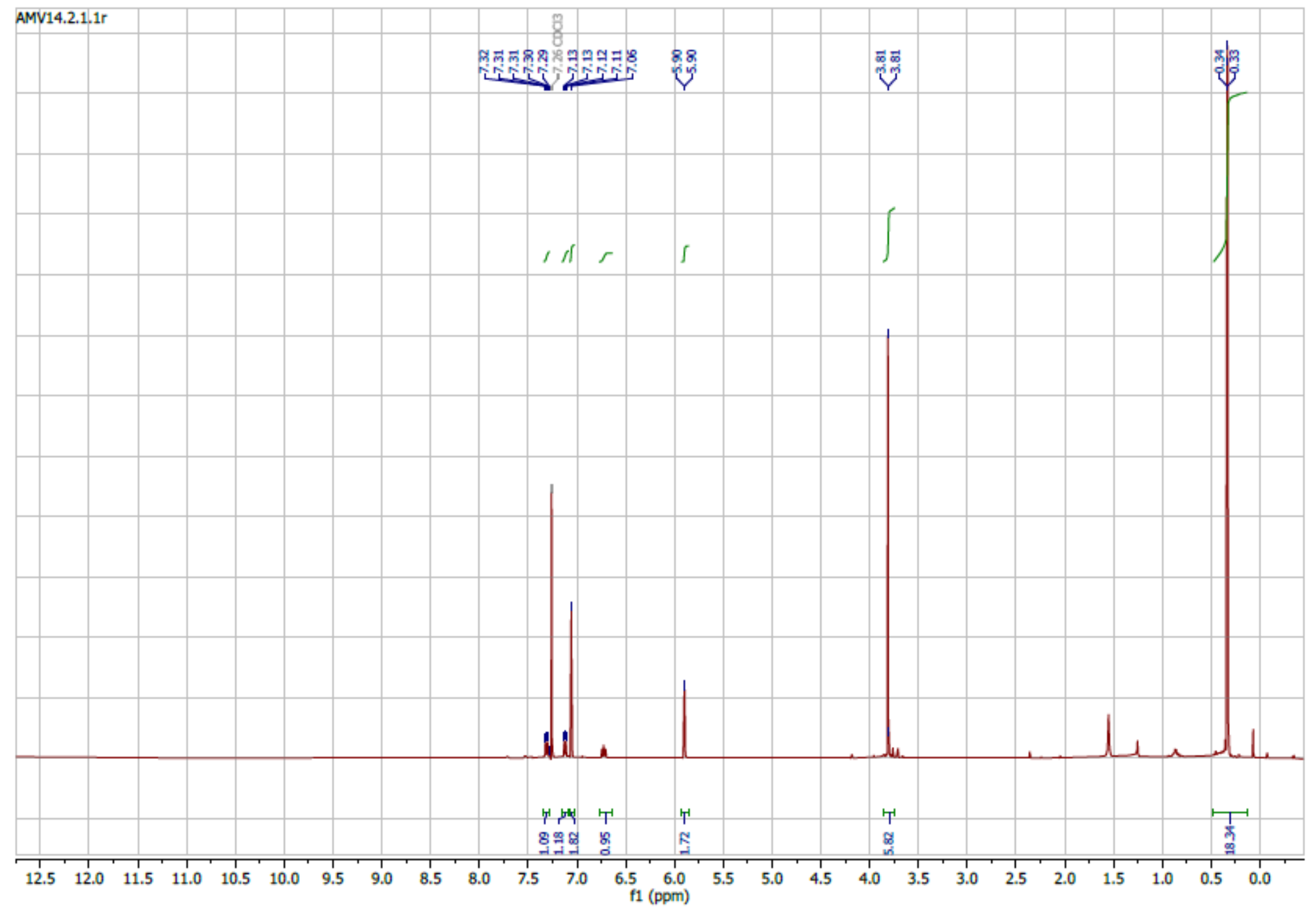

Figure S14. ${ }^{1} \mathrm{H} \mathrm{NMR}$ spectrum $\left(500 \mathrm{MHz}, \mathrm{CDCl}_{3}\right)$ of compound $\mathbf{S 6}$. 


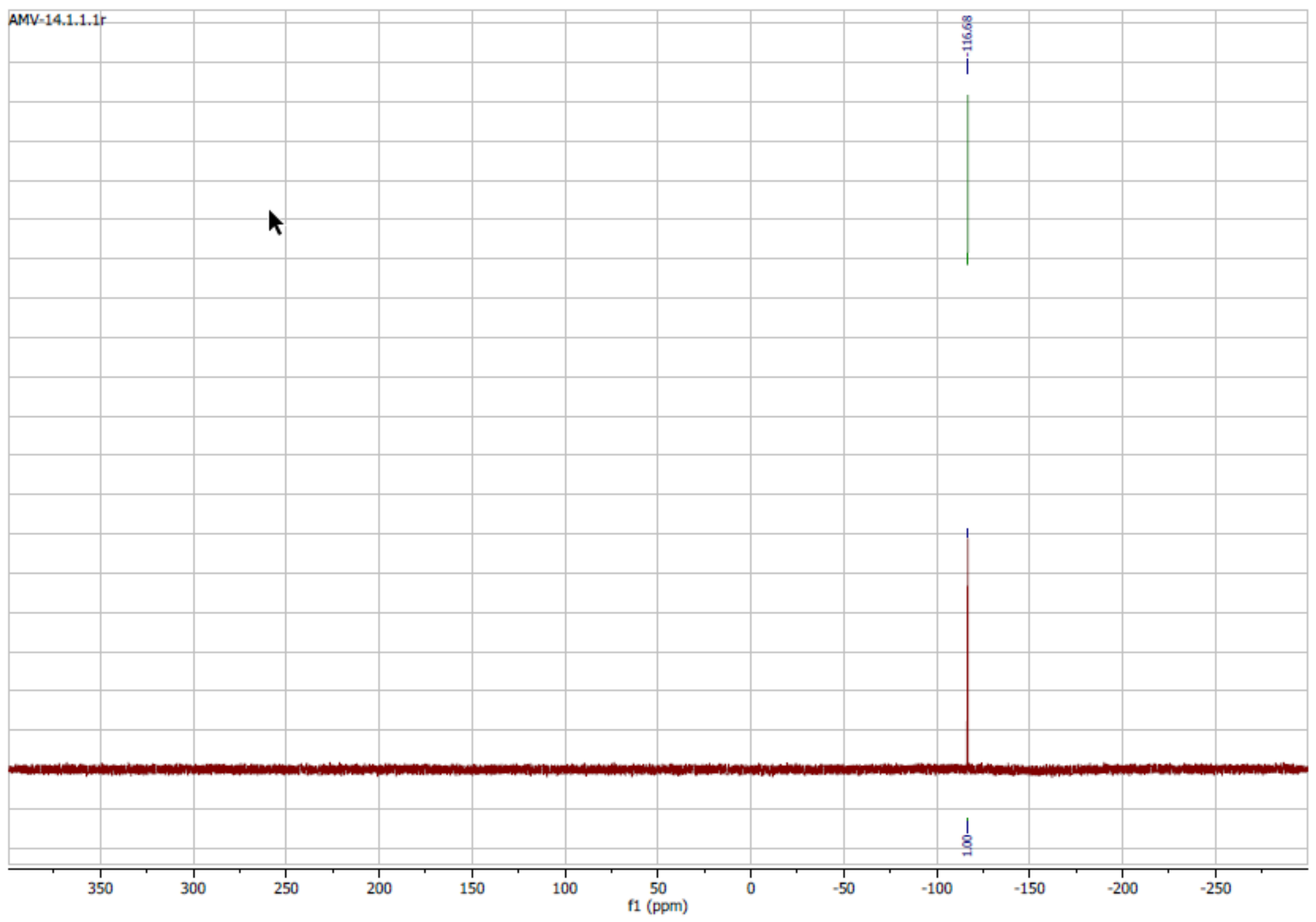

Figure S15. ${ }^{19} \mathrm{~F}$ NMR spectrum (282 $\left.\mathrm{MHz}, \mathrm{CDCl}_{3}\right)$ of compound $\mathbf{S 6}$. 


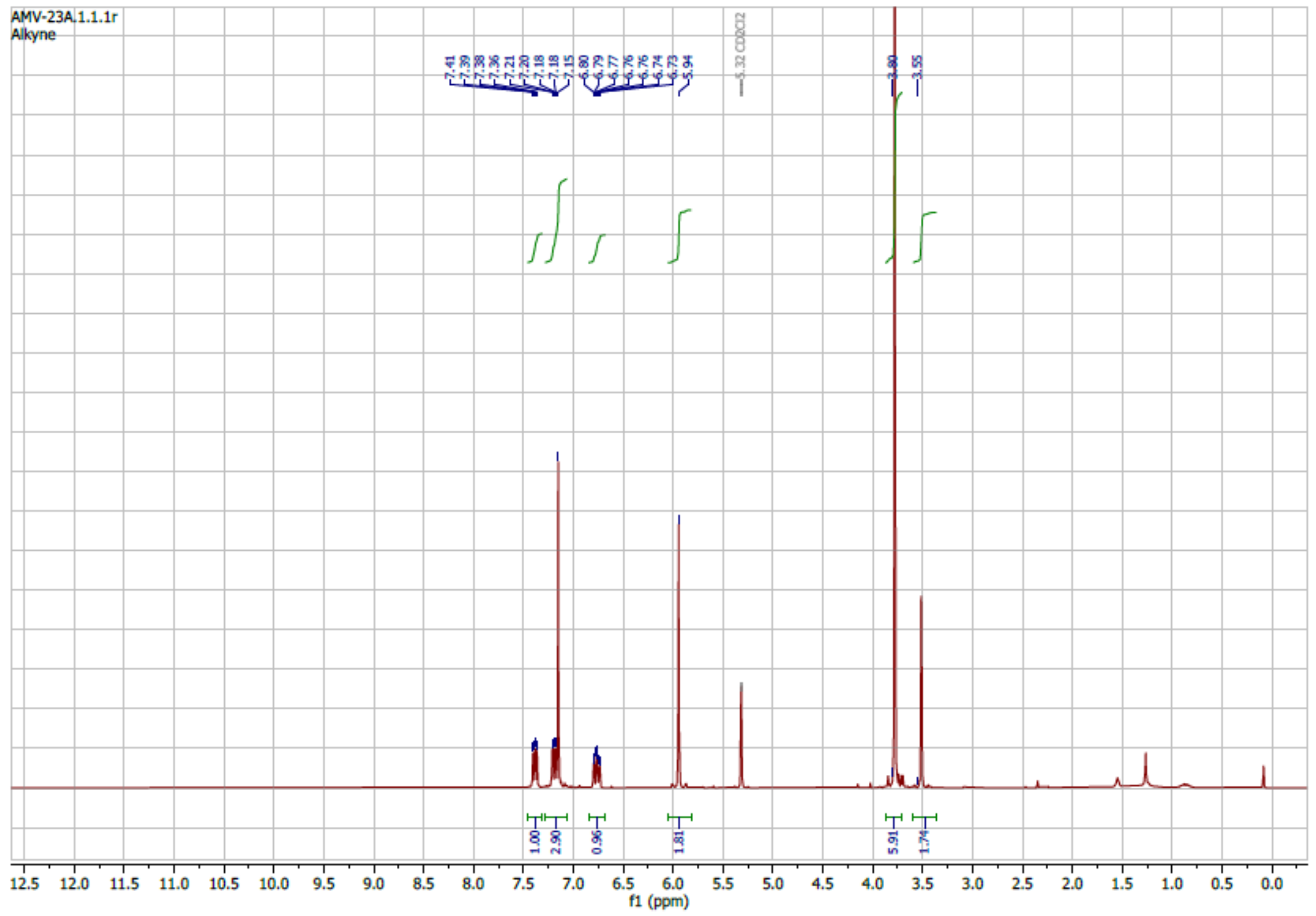

Figure S16. ${ }^{1} \mathrm{H}$ NMR spectrum $\left(300 \mathrm{MHz}, \mathrm{CD}_{2} \mathrm{Cl}_{2}\right)$ of compound $\mathbf{S} 7$. 


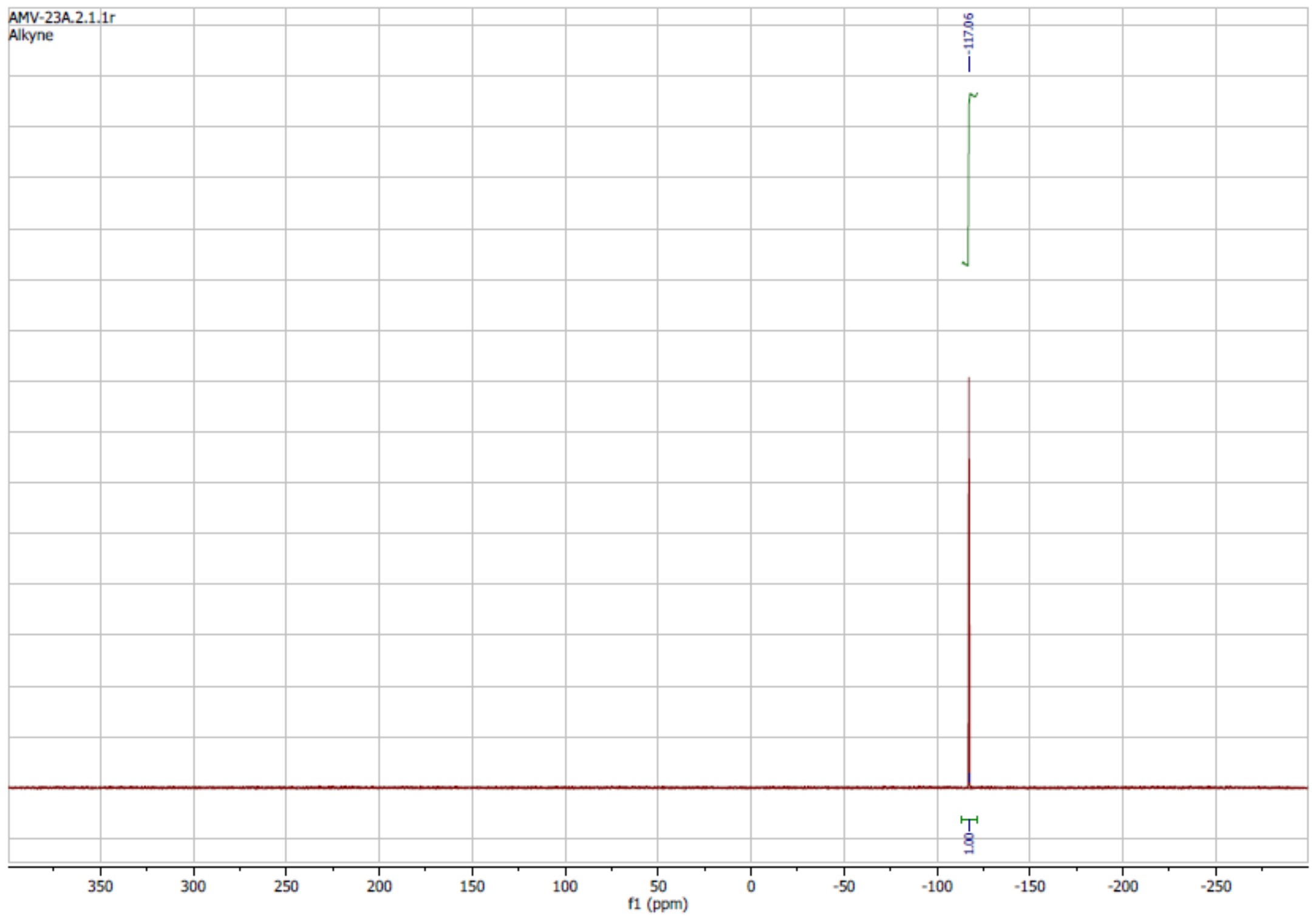

Figure S17. ${ }^{19} \mathrm{~F}$ NMR spectrum $\left(471 \mathrm{MHz}, \mathrm{CD}_{2} \mathrm{Cl}_{2}\right.$ ) of compound $\mathbf{S 7}$. 


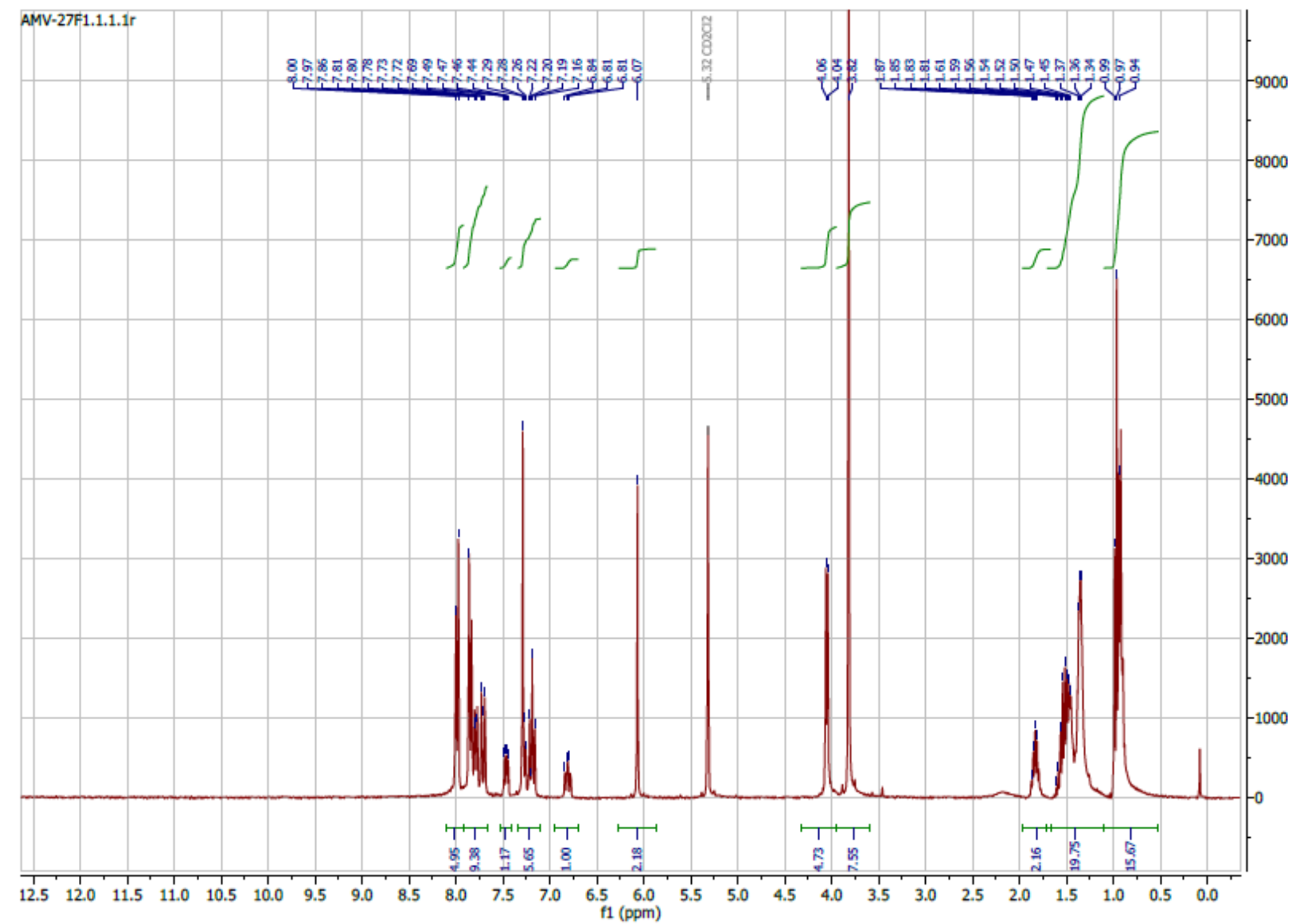

Figure S18. ${ }^{1} \mathrm{H}$ NMR spectrum $\left(300 \mathrm{MHz}, \mathrm{CD}_{2} \mathrm{Cl}_{2}\right)$ of compound 1. 


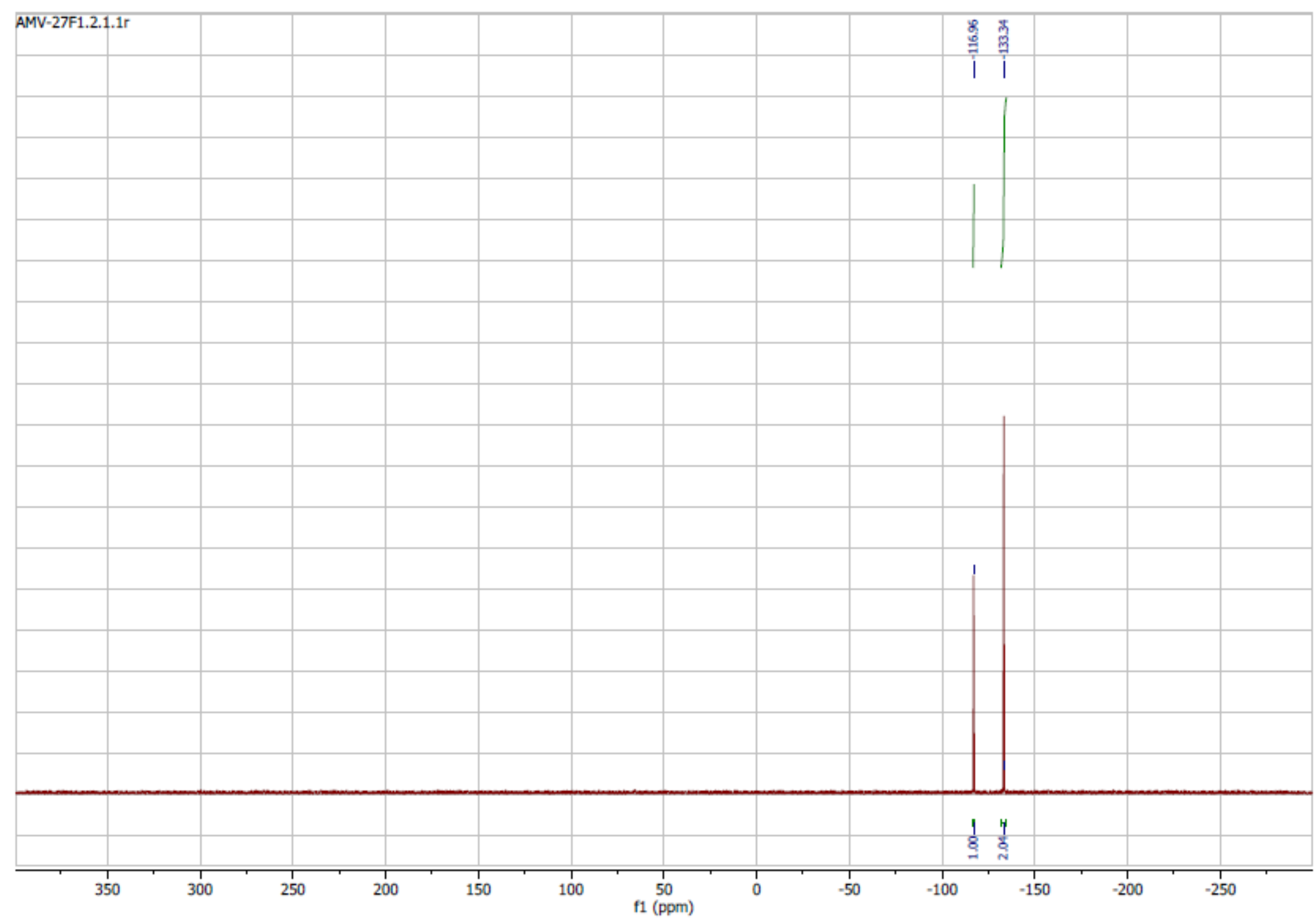

Figure S19. ${ }^{19} \mathrm{~F}$ NMR spectrum $\left(471 \mathrm{MHz}, \mathrm{CD}_{2} \mathrm{Cl}_{2}\right)$ of compound 1. 


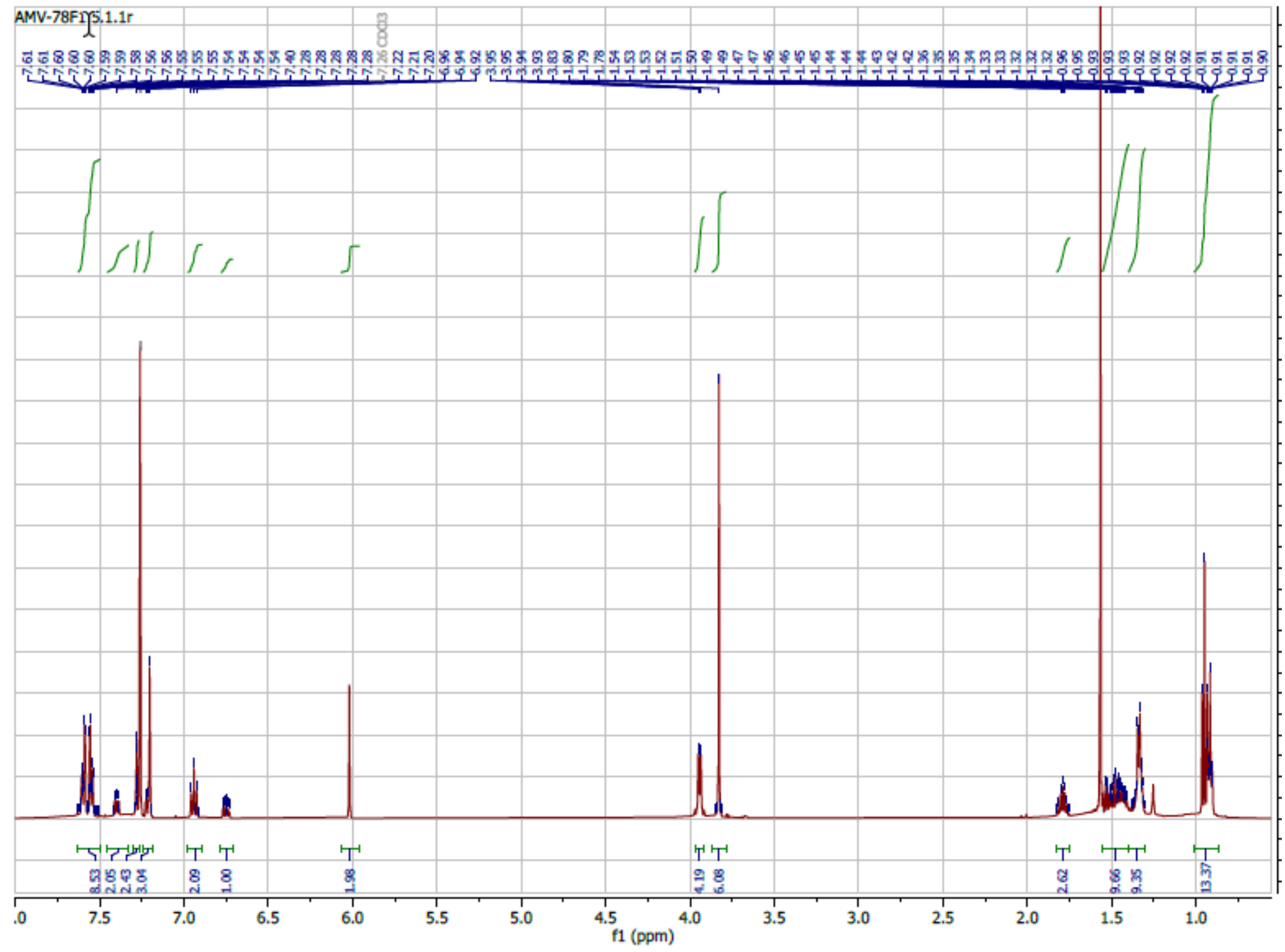

Figure S20. ${ }^{1} \mathrm{H}$ NMR spectrum $\left(500 \mathrm{MHz}, \mathrm{CDCl}_{3}\right)$ of photoproduct 3. 


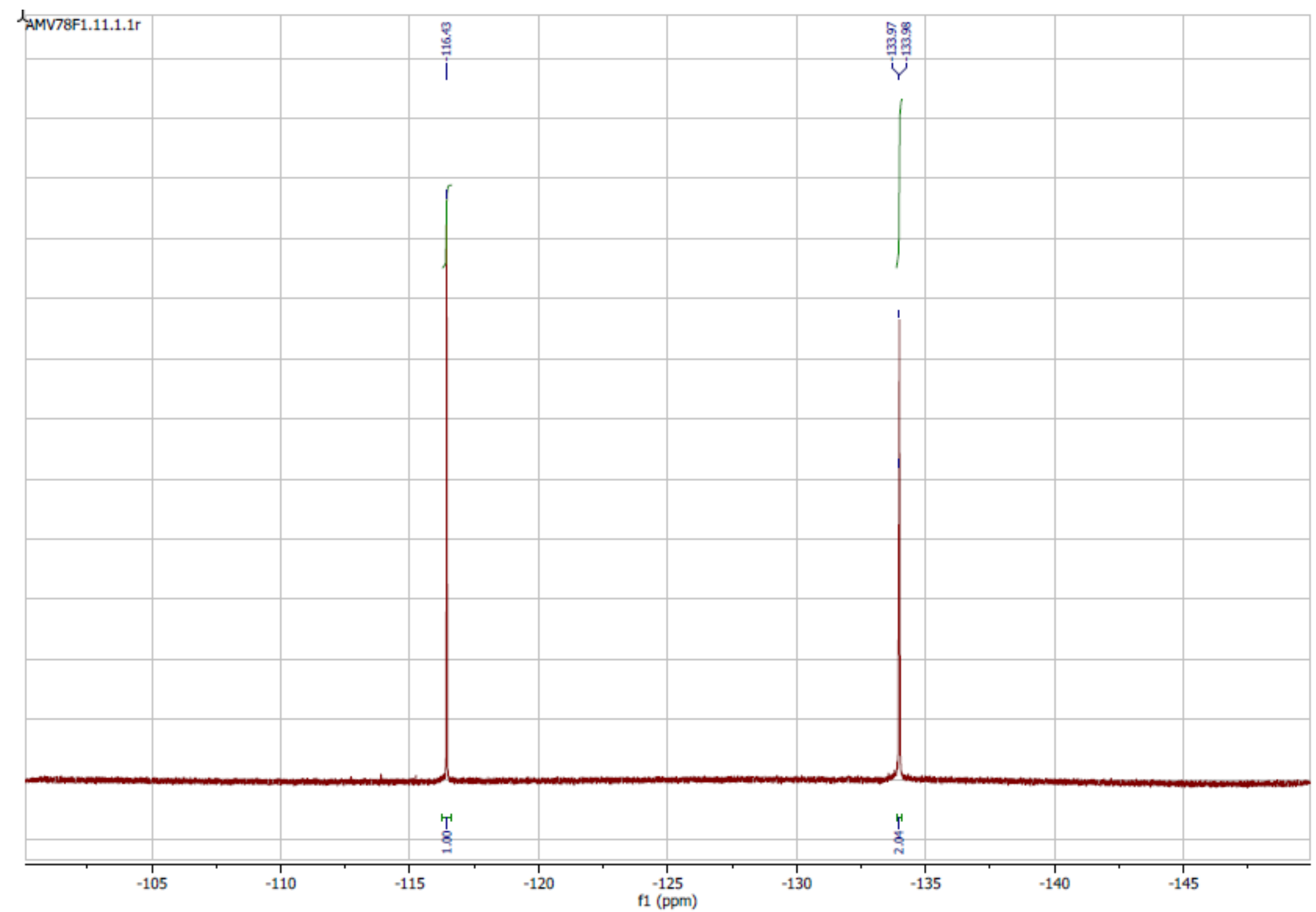

Figure S21. ${ }^{19} \mathrm{~F}$ NMR spectrum $\left(471 \mathrm{MHz}, \mathrm{CD}_{2} \mathrm{Cl}_{2}\right)$ of photoproduct 3. 


\section{$\underline{\text { References }}$}

(1) Love, B. E.; Jones, E. G. The Use of Salicylaldehyde Phenylhydrazone as an Indicator for the Titration of Organometallic Reagents. J. Org. Chem. 1999, 64, 3755-3756.

(2) Poloukhtine, A.; Popik, V. V. Highly Efficient Photochemical Generation of a Triple Bond: Synthesis, Properties, and Photodecarbonylation of Cyclopropenones. J. Org. Chem. 2003, 68, 7833-7840.

(3) Chen, Z.; Swager, T. M. Synthesis and Characterization of Fluorescent Acenequinones as Dyes for Guest-Host Liquid Crystal Displays. Org. Lett. 2007, 9, 997-1000.

(4) Cox, J. R.; Simpson, J. H.; Swager, T. M. Photoalignment Layers for Liquid Crystals from the Di- $\pi$-methane Rearrangement. J. Am. Chem. Soc. 2013, 135, 640-643.

(5) Gaussian 16, Revision A.03, Frisch, M. J.; Trucks, G. W.; Schlegel, H. B.; Scuseria, G. E.; Robb, M. A.; Cheeseman, J. R.; Scalmani, G.; Barone, V.; Petersson, G. A.; Nakatsuji, H.; Li, X.; Caricato, M.; Marenich, A. V.; Bloino, J.; Janesko, B. G.; Gomperts, R.; Mennucci, B.; Hratchian, H. P.; Ortiz, J. V.; Izmaylov, A. F.; Sonnenberg, J. L.; Williams-Young, D.; Ding, F.; Lipparini, F.; Egidi, F.; Goings, J.; Peng, B.; Petrone, A.; Henderson, T.; Ranasinghe, D.; Zakrzewski, V. G.; Gao, J.; Rega, N.; Zheng, G.; Liang, W.; Hada, M.; Ehara, M.; Toyota, K.; Fukuda, R.; Hasegawa, J.; Ishida, M.; Nakajima, T.; Honda, Y.; Kitao, O.; Nakai, H.; Vreven, T.; Throssell, K.; Montgomery, J. A., Jr.; Peralta, J. E.; Ogliaro, F.; Bearpark, M. J.; Heyd, J. J.; Brothers, E. N.; Kudin, K. N.; Staroverov, V. N.; Keith, T. A.; Kobayashi, R.; Normand, J.; Raghavachari, K.; Rendell, A. P.; Burant, J. C.; Iyengar, S. S.; Tomasi, J.; Cossi, M.; Millam, J. M.; Klene, M.; Adamo, C.; Cammi, R.; Ochterski, J. W.; Martin, R. L.; Morokuma, K.; Farkas, O.; Foresman, J. B.; Fox, D. J. Gaussian, Inc., Wallingford CT, 2016.

(6) GaussView, Version 6.0.16, Dennington, R.; Keith, T. A.; Millam, J. M. Semichem Inc., Shawnee Mission, KS, 2016. 